\title{
Reservoir characterization for sweet spot detection using color transformation overlay scheme
}

\author{
Atif Ismail $^{1} \cdot$ Arshad Raza $^{2}$ (D) Raoof Gholami ${ }^{3} \cdot$ Reza Rezaee $^{4}$
}

Received: 20 February 2020 / Accepted: 11 May 2020 / Published online: 22 May 2020

(c) The Author(s) 2020

\begin{abstract}
Reservoir characterization carried out for the quantitative representation of a reservoir leads to effectively managing the hydrocarbon reservoir. There have been few attempts made to characterize the reservoir and assess the potential of a reservoir for the sweet spots using seismic, geomechanical, and petrophysical characteristics where a combination of seismic and petrophysical characters is often ignored given the complexity of such integration. To the best of our knowledge, none of the studies have provided overall reservoir characterization workflows using the combination of petrophysical and geomechanical attributes for sweet spot detection. This study aims to adopt a new color transformation overlay scheme to assess the potential of reservoirs by identifying the sweet spots that can guide to propose a location for a new well. The core scale measurements and well log interpretation were used to determine the petrophysical and geomechanical properties of a highly complex sandstone reservoir which were used as the input to build a 3D reservoir model. The results obtained indicated that predicting the distribution of sweet spots is an effective scheme for well-planning and field development in the region. Four sweet spots are identified in the studied reservoir based on the color transformation overlay approach which has heterogeneous continuity behavior in vertical and horizontal directions. The identification of sweet spots based on top view is not enough for the complete understanding of spreading in all directions. Cross-sectional analysis of the color transformation overlay model revealed that there is a sweet spot near Well-E in west which has ideal reservoir potential and place to consider another proposed well.
\end{abstract}

Keywords Reservoir characterization · Sweet spots $\cdot$ Petrophysics $\cdot$ Geomechanical modeling $\cdot$ Sandstone $\cdot$ Color transform

\section{Introduction}

Reservoir characterization is a major part of reservoir development and management strategies (Abdel-Fattah et al. 2020; Bhuiyan and Hossain 2020). It helps to develop predictive reservoir simulation models for the distribution of hydrocarbons and flow properties in hydrocarbon reservoirs based on the overlapping contribution of geophysical,

Arshad Raza

Arshadraza212@gmail.com

1 Department of Geological Engineering, University of Engineering and Technology (UET), Lahore, Pakistan

2 Department of Petroleum Engineering, University of Engineering and Technology (UET), Lahore, Pakistan

3 Department of Petroleum Engineering, Curtin University, Sarawak, Malaysia

4 WA School of Mines: Minerals Energy and Chemical Engineering, Curtin University, Bentley, Australia geological, petrophysical, and engineering information (Al-Amri et al. 2017; Chopra and Michelena 2011; Gaafar et al. 2015). Technically speaking, the production and life of the reservoir can be improved by characterizing its petrophysical, geomechanical, geological, and geophysical aspects (Sun et al. 2015). A combination of wireline logging and core analysis data can be a good source to determine these aspects (Elnaggar et al. 2018; Sun et al. 2015). However, variations of petrophysical properties are often controlled by disparities in the facies attributes of the reservoir and are not easy to identify (Thadani 1992). This can be resolved by the help of advanced computational approaches where the spatial distribution of the petrophysical properties of a reservoir can be understood efficiently by generating 3D reservoir models (Adeoti et al. 2014). Statistical approaches are perhaps the best methods under these circumstances which can provide visualization on the spatial distribution of the reservoir heterogeneity and reduce the error in the reservoir models (Damsleth 1994). 
Geostatistics is one of the categories of applied statistics used in the reservoir characterization and determination of the spatial distribution of reservoir properties in 2D or 3D spaces (Saccomano and Savioli 2007). Geostatistical methods can be applied to interpolate the reservoir properties between different wells where data and information are missing (Fegh et al. 2013). Usually, sequential Gaussian simulation is used as a geostatistical method for petrophysical evaluation where iteration is considered to properly estimate different properties at each grid cell from probability distribution functions (Fegh et al. 2013; Kelkar et al. 2002). On these occasions, the petrophysical characterization of the heterogeneous reservoir is initially carried out based on the continuous and spatial distribution (Jennings and Lucia 2003) which is followed by the structural modeling using the three-dimensional grid (Holden et al. 2003; Alfaaouri et al. 2009). Upon structural modeling, the petrophysical properties of each layer in the model are determined/populated using the geostatistical techniques over layers.

The sweet spot is economically attractive and easy to access part of the reservoir (Tennant and Giles 2014). Practically, the sweet spot analysis requires the integration of petrophysics, geomechanics, geophysics, and structural data (Alshakhs and Rezaee 2019). Upon integration and generation of the 3D spatial framework using the geostatistical methods, sweet spots can be delineated in space (Liang et al. 2016). Reserve estimation can then be done using the discriminant analysis of the geological, geomechanical, and petrophysical characteristics (Aliouane and Ouadfeul 2014). There have only been few studies so far discussing on the sweet spot identifications using seismic (Changzi et al. 2014; Glaser et al. 2013; Qingcai et al. 2018; Sena et al. 2011), petrophysical (Kormaksson et al. 2015), and geomechanical characterization (Rahman and Gui 2016; Rojas et al. 2016) where the combination of seismic and petrophysical characters is often ignored given the complexity of such integration (Aliouane and Ouadfeul 2014; Yang et al. 2015).

Considering the importance of sweet spot detection and related studies carried out considering different attributes, less attention has been given to the interplay of petrophysical and geomechanical for sweet spot detection. This study aims to carry out integrated reservoir characterization by a combination of petrophysical and geomechanical data for the identification of sweet spots using reservoir cross-sectional and color transformation approach. The core scale measurements and well log interpretation are used to determine the petrophysical and geomechanical properties of a highly complex sandstone reservoir which were used as the input to build a $3 \mathrm{D}$ reservoir model.

\section{Study area}

The study area of this research is part of the Sawan gas field located in the Middle Indus basin of Pakistan (see Fig. 1 ) where most of the production is coming from the Lower Goru Formation. The discovery of the Sawan gas field dates back to 1998, while the operations for commercial production were started in 2003. The highest expected recovery of $1 \mathrm{TCF}$ (trillion cubic feet) puts it among the largest gas fields in Pakistan (Kadri 1995). Goru Formation consists of shales, sandstone, siltstone, and limestone lithology (Kazmi and Jan 1997). The sandy zone of the Lower Goru Formation is generally divided into four sandstone intervals (Ahmad and Chaudhry 2002).). The studied formation is sandwiched between Parh Formation and Sembar Formation of Cretaceous age. The petroleum plays associated with Sembar-Goru rocks are mostly gas producing. In the studied area, the sands of the Lower Goru Formation act as a reservoir rock (Munir et al. 2011). The upper Goru Formation consists of shale lithology which is a seal rock, while underlying Sembar shale is considered as a source rock as shown in Fig. 2. It has been reported by Krois et al. (1998) that there is a 30 million-year time gap between the Lower Goru Formation and the Sembar Formation due to sea-level lowstand (Krois et al. 1998).

The studied reservoir is classified into sublitharenite to feldspathic litharenite and lithic arkoses sections (see Fig. 3) (Berger et al. 2009). Carbonate fragments, muscovite, altered biotite, tourmaline, and zircon are considered as accessory minerals in the reservoir. Related to sandstone texture, the sandstones are coarse grained and moderately to well sorted in the reservoir intervals. Sandstone is rarely present in the upper part of the Goru Formation, while it dominates in the lower part where it becomes the reservoir, successfully producing in different fields of Pakistan (Ahmad and Chaudhry 2002; Ismail et al. 2017b; Kadri 1995).

The sand-shale intercalations have zones with very good petrophysical properties at a reservoir temperature of $175^{\circ} \mathrm{C}$. In $\mathrm{C}$-sand of Lower Goru Formation, chamosite and illite are present as dominant iron-rich clays (Berger et al. 2009). The porosity and air permeability of the C-sand interval is 6-30\% and $0.01-1252 \mathrm{mD}$, respectively, as per routine core analysis (Ismail et al. 2018). Cretaceous shale of the Goru Formation shows good source rock characteristics because it contains abundant organic matter and possibly deposited after transportation from Indian Shield because there is high sand content on the eastern part of the basin as compared to western part (Kadri 1995). High thickness and organic content of the shales constitute as a perfect source rock for reservoir sands of Goru Formation (Sahito et al. 2013; Wandrey et al. 2004). The depositional 

studied area in Pakistan
Fig. 1 Location map of the

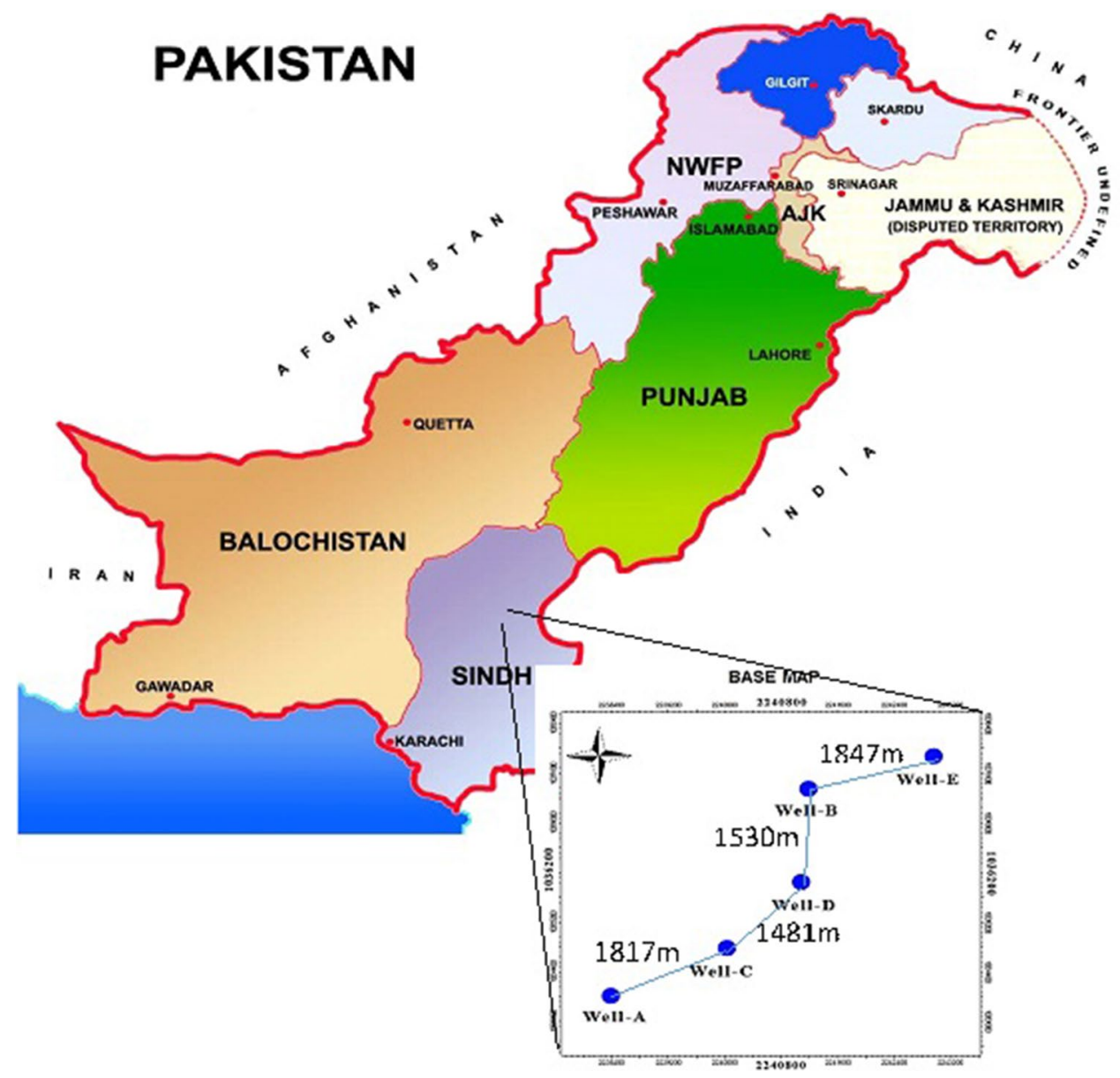

environment of this area shows the shallow marine deposition of medium to coarse grain sandstone. The study area is located in Middle Indus Basin which is separated from Upper Indus Basin by a geological feature named Sargodha High. From east to west, based on Indian Shield topography and later development, Central Indus Basin is divided into three parts as Punjab Platform, Sulaiman Depression, and Sulaiman Fold Belt (Ahmed 1992).

It is surrounded by Indian Shield in east, Kirther ranges in west, thrust belt in northwest, and Khairpur Highs in the south direction (Azeem et al. 2018). The location of the southeastern and eastern edge of the Khairpur high is one of the biggest factors for the formation of traps in the nearby fields. The three tectonic rifting occasions in this area are uplift and inversion in the late Cretaceous age, wrenching in the late Paleocene age and uplift of the Khairpur high in the recent age (Ahmad and Chaudhry 2002). A structural dip toward SE and reduction of the petrophysical properties are the root behind the trapping mechanism in this area. The structural dip shows the offlap structure formed due to the regression of the sea as shown in Fig. 2. The reservoir is resultant of the proximal delta system under high wave action and barrier bar (Berger et al. 2009).

\section{Materials and methods}

In this study, core data and wireline log data were available for facies, petrophysical, and geomechanical analysis and considered for the 3D reservoir modeling of the studied reservoir. Well logs from 05 wells (A-E) including gamma ray, resistivity, $\mathrm{P}$-wave sonic, $\mathrm{S}$-wave sonic, density, and mud logs were used in this study. A total number of 237 core samples were acquired from the C-sand interval of the lower Goru in Well-B and Well-C as data are given in Table 1 including porosity and permeability data which were also taken from the literature (Berger et al. 2009). Characterization of the reservoir in this study was divided into two parts: (1) calculation of the petrophysical and geomechanical properties of the reservoir and (2) 3D reservoir modeling as depicted in the detailed methodology diagram used in this study shown in Fig. 4.

Petrophysical and geomechanical properties of the reservoir were calculated using wireline log data of the studied interval of the Lower Goru Formation (see Fig. 3). To estimate the effective porosity, permeability, and hydrocarbon saturation, conventional analytical approaches were used. The effective porosity was determined using 

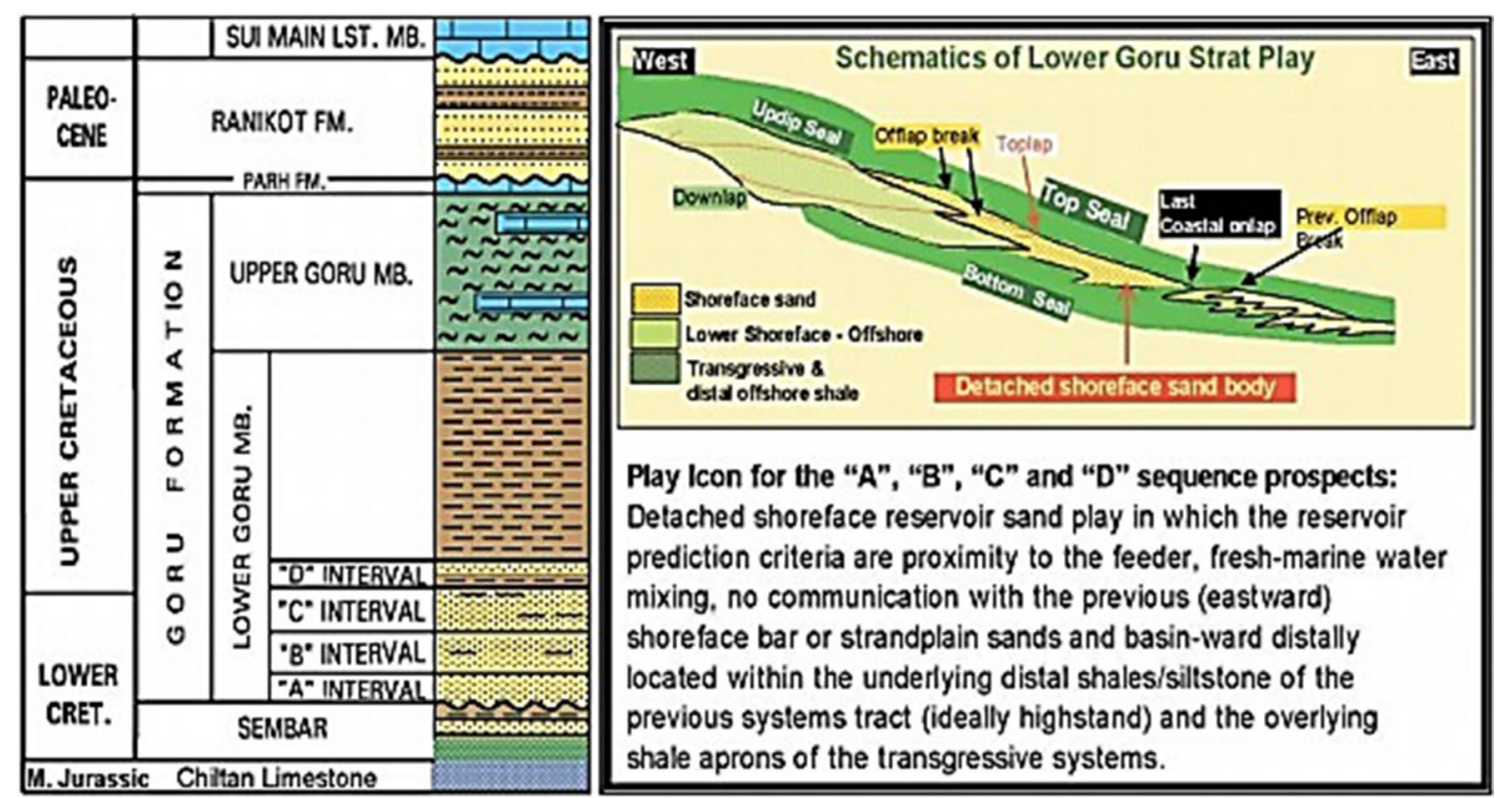

Fig. 2 Stratigraphic distribution of Goru Formation (Ahmad et al. 2004)

Fig. 3 Classification of lower Goru sandstone (C-interval) (Berger et al. 2009)

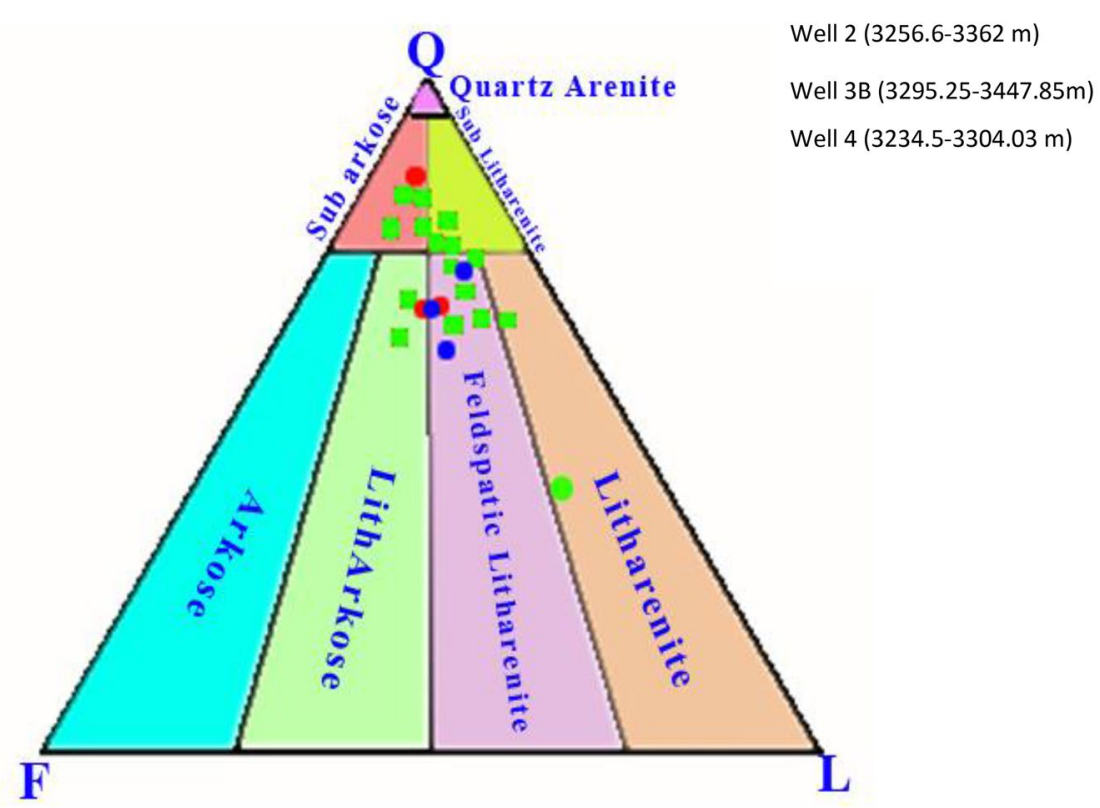

the volume of shale. Permeability was estimated using the correlation proposed by Morris and Biggs (1967) where permeability is expressed in terms of irreducible water bulk volume. It was studied that Morris and Biggs were predicting the permeability better than neural network in the studied formation. Due to heterogeneities of the formation, the neural network was not able to generalize the behavior of the permeability in the training phase. On hard training of the artificial neural network, the problem of overfitting was seen. Hence, Morris and
Biggs were preferred in this study to generalize the permeability behavior spatially across the reservoir (Ismail et al. 2017a).

Effective porosity, permeability, and hydrocarbon saturation were determined using log information of the wells. The following approaches were used for the estimation of above-discussed properties:

The effective porosity $\left(\phi_{\text {eff }}\right)$ was estimated using the total porosity $\left(\phi_{\mathrm{t}}\right)$ and volume of shale $\left(V_{\mathrm{sh}}\right)$ of the reservoir. 
Table 1 Routine core analysis data of Well-C and Well-B

\begin{tabular}{|c|c|c|c|c|c|}
\hline \multicolumn{3}{|l|}{ Well-C } & \multicolumn{3}{|l|}{ Well-B } \\
\hline Depth (m) & $\begin{array}{l}\text { Perme- } \\
\text { ability } \\
(\mathrm{mD})\end{array}$ & $\begin{array}{l}\text { Porosity } \\
(\%)\end{array}$ & Depth (m) & $\begin{array}{l}\text { Perme- } \\
\text { ability } \\
(\mathrm{mD})\end{array}$ & $\begin{array}{l}\text { Porosity } \\
(\%)\end{array}$ \\
\hline 3256.90 & 0.07 & 2.66 & 3258.6 & 0.03 & 11.23 \\
\hline 3257.95 & 0.21 & 1.74 & 3264.6 & 0.12 & 14.23 \\
\hline 3258.90 & 0.05 & 0.89 & 3269.6 & 0.13 & 15.6 \\
\hline 3260.90 & 0.02 & 7.29 & 3275.9 & 1.7 & 14.53 \\
\hline 3261.30 & 0.03 & 7.25 & 3278.3 & 20.15 & 15.57 \\
\hline 3261.60 & 0.08 & 16.61 & 3283.6 & 12.2 & 14.66 \\
\hline 3337.85 & 1.5 & 0.64 & 3357.9 & 0.66 & 8.8 \\
\hline 3338.15 & 3 & 0.22 & 3362.3 & 0.21 & 9.6 \\
\hline
\end{tabular}

$\phi_{\text {eff }}=\phi_{\mathrm{t}}\left(1-V_{\mathrm{sh}}\right)$

In Eq. (1), the volume of shale was computed by the substitution of the gamma ray index into the nonlinear relationships (Tiab and Donaldson 2011).

Permeability was estimated using Morris and Biggs's (1967) correlation, in which permeability is expressed in terms of irreducible water bulk volume $\left(V_{\text {bwi }}\right)$ instead of irreducible water saturation. All the variables, total porosity and irreducible water bulk volume required for permeability $(k)$ estimation were calculated using analysis of the wireline logs. $k=\left[100 \times \frac{\varphi_{\mathrm{eff}}^{2}\left(\phi_{\mathrm{t}}-V_{\mathrm{bwi}}\right)}{V_{\mathrm{bwi}}}\right]^{2}$

The estimation of water saturation $\left(S_{\mathrm{w}}\right)$ was made using Archie's equation (Archie 1942).

$S_{\mathrm{w}}^{\mathrm{n}}=\frac{a R_{\mathrm{w}}}{\phi_{\mathrm{t}}^{\mathrm{m}} R_{\mathrm{t}}}$

$S_{\mathrm{h}}=1-S_{\mathrm{w}}$

where $R_{\mathrm{w}}$ is resistivity of water; $n$, saturation exponent; $m$, cementation exponent; $S_{\mathrm{h}}$, hydrocarbon saturation; $R_{\mathrm{t}}$, true resistivity; $a$, tortuosity factor.

The mechanical properties of the reservoir can be estimated by applying load on the test specimen and measurement of elastic wave properties (Sharma and Arya 2006). Young's modulus and Poisson's ratio are important parameters to define the brittleness of the reservoir (Jahandideh and Jafarpour 2016). The hydraulic fracturing operations and wellbore stability analysis design depend upon the variation of brittleness in the reservoir (Charlez 1997).

Young's modulus ( $E$, in GPa units) can be estimated using shear wave velocity $\left(V_{\mathrm{p}}\right)$, sonic wave velocity information $\left(V_{\mathrm{s}}\right)$, and bulk density $\left(\rho_{\mathrm{b}}\right)$ (Mukerji and Dvorkin 2009).

$E=\rho_{\mathrm{b}} V_{\mathrm{s}}^{2}\left(\frac{3 V_{\mathrm{p}}^{2}-4 V_{\mathrm{s}}^{2}}{V_{\mathrm{p}}^{2}-V_{\mathrm{s}}^{2}}\right) \times 10^{-6}$
Fig. 4 Workflow of the methodology used in this study

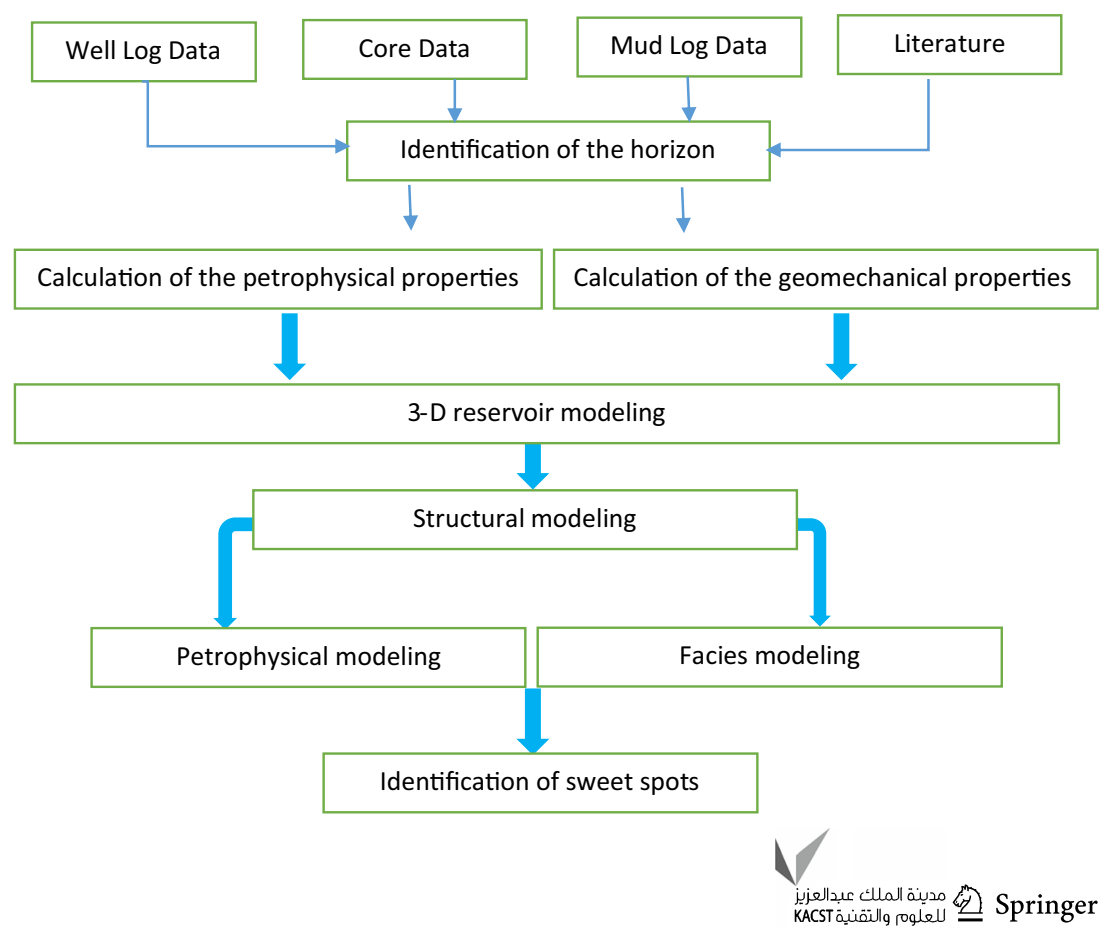


Subsequently, bulk modulus $(K)$ can then be determined by empirical relationships using Young's modulus and Poisson's ratio ( $\nu$ ) (Archer and Rasouli 2012).

$K=\frac{E}{3(1-2 v)}$

The shear modulus $(G)$ can be estimated using bulk density and shear velocity information (Mukerji and Dvorkin 2009). Shear velocity is estimated using shear transit time which is obtained from the shear sonic log of all wells.

$G_{\text {dynamic }}=\rho_{\mathrm{b}} V_{\mathrm{s}}^{2}$

Poisson's ratio can be expressed in terms of bulk modulus and shear modulus (Stein 1976).

$v=\frac{3 K-2 G}{6 K+2 G}$

The brittleness index (BI) can be estimated by using equation (Grieser and Bray 2007).

$$
\begin{aligned}
& E_{\text {Brittleness }}=\frac{E-E_{\max }}{E_{\max }-E_{\min }} \\
& v_{\text {Brittleness }}=\frac{v-v_{\max }}{v_{\min }-v_{\max }}
\end{aligned}
$$

Brittleness Index $=\frac{E_{\text {Brittleness }}+v_{\text {Brittleness }}}{2}$

where $E_{\text {brittleness }}$ is brittleness from Young's modulus; $E_{\max }$, maximum Young's modulus; $E_{\mathrm{min}}$, minimum Young's modulus; $\nu_{\text {brittleness }}$, Poisson's ratio brittleness; $\nu_{\max }$, maximum Poisson's ratio; $\nu_{\min }$, minimum Poisson's ratio

The above-discussed workflow gives a detailed overview of the petrophysical and geomechanical properties using wireline logs.

Elastic parameters of the reservoir, including Young's modulus and Poisson's ratio, were estimated using the conventional dynamic elastic equations where sonic and density logs are required (Fjar et al. 2008). Having Young's modulus and Poisson's ratio, the brittleness index (BI) which is required to evaluate the fracability of the reservoir can be estimated using the following equation (Grieser and Bray 2007):

Brittleness Index $=\frac{E_{\text {Brittleness }}+v_{\text {Brittleness }}}{2}$

The estimated porosity and permeability were drawn on the same scale with routine core analysis testing to check the accuracy of the calculations in Well-B and Well-C. In Well$\mathrm{B}$ there was relatively good matching between the estimated total porosity and permeability, while in Well-C there was not very good matching between the estimated petrophysical properties and routine core analysis. Such variation between the petrophysical properties matching is due to heterogeneities in the formation that causes the wireline logging to skip the litho-information excessively. By application of Dykastra and Parsons's (1950) approach (Dykstra and Parsons 1950), it was found that Goru Formation is a very heterogeneous formation (Ismail et al. 2017b). In the selection of constant in the estimation of permeability, it was taken into consideration that there should not be a problem of overfitting in the calculation because in such cases, this could lead to failure of the 3D petrophysical models to generalize the trend in the whole reservoir area.

To build the reservoir model, the structural modeling was done by horizon mapping, generation of the surface, zoning, and vertical layering. The structural model is the generation of the skeleton that has all the information related to the structural features of the reservoir. For the structural modeling of the reservoir, horizon maps of the reservoir were prepared. The reservoir thickness in Well-C, Well-D, and Well-B is relatively consistent compared to Well-A and Well-E. The deepest point of the reservoir bottom hit by any well in the studied reservoir was $3398 \mathrm{~m}$. Figure 5 shows the upper and lower structural map of the reservoir near Well-A and Well-E.

Reservoir modeling was preliminarily performed on the grid structure of $92 \times 78 \times 10(71,760$ cells $)$. The upscaling of the wells logs was unable to pick the thin shale layers in the reservoir. The reservoir layers which have high producible hydrocarbon were not taken into consideration in the $3 \mathrm{Dl}$ model. The upscaled reservoir model was not corresponding to estimated lithological features from well $\log$ analysis, and the geological features smaller than the grid layering had been ignored by the upscaled well logs. This leads to the construction of the reservoir model which may have enough grid cells and layers to pick the lithological and petrophysical information of the reservoir-X. The high-resolution model was prepared with dimensions of $920 \times 780 \times 100(72,649,401$ cells $)$.

Structural modeling was followed in the next phase by the property modeling where attempts were made to understand the potential areas and spatial heterogeneity in the reservoir. At this stage, the property modeling was done in such a way that the heterogeneities of the formations would not be neglected during modeling. Thus, porosity, permeability, water saturation, Young's modulus, Poisson's ratio, and brittleness were populated in the gridded structure of the reservoir. The Gaussian indicating simulator was used for the reservoir modeling of the facies discrete data, while the Gaussian sequential algorithm was used for the continuous information of petrophysical and geomechanical properties.

Facies modeling depends upon the quality and quantity of petrophysical data of the reservoir. With the help 

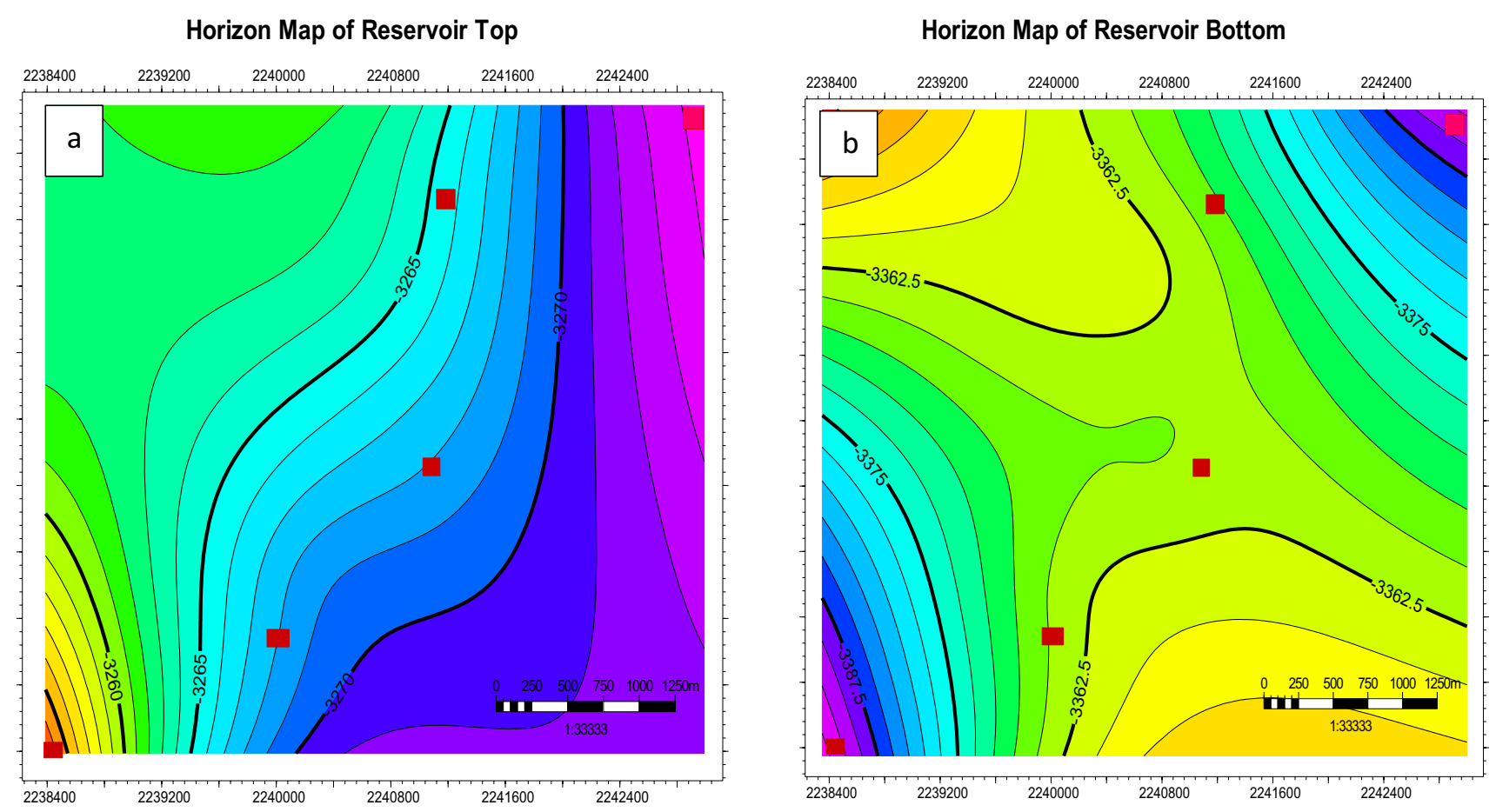

Fig. 5 Upper horizon map (left) and lower horizon map (right) of the studied formation

of facies analysis, we acquire information regarding the three-dimensional lithology changes in the reservoir that locates major reservoir zones are capable of creating difficulties in the identification of potential zone to drill and understanding of the lateral extent of reservoir interval in production strategies (Martin and Malone 2017). Property modeling involves facies modeling in the initial phase of the reservoir modeling. For the facies model, gamma ray information was used for the facies considering sandstone, shaly sandstone, and shale as major lithology. As a result, the reservoir was divided into sandstone, shaly sandstone, and shale lithology (Fig. 6). Facies information was scaled up for the generation of 3D facies model. Lithological information was populated in the gridded structure using Sequential Indicator Simulation. For the development of a high-resolution model, 100 layers were selected after the hit and trial approach for a true representation of facies information from well logs. Good matching was obtained between the proportion curves of well log analysis and facies proportion of 3D facies modeling (see Fig. 6). Looking at this figure, it can be seen that the upper part of the reservoir had sandstone as dominant lithology while at the bottom of the reservoir shale was dominant. The upscaled log was not able to copy the facies information less thickness of the selected layers in the studied reservoir as shown in Fig. 6.

The variations in the distribution of the estimated petrophysical properties were assessed on the basis of histogram analysis using Petrel software as given in Figs. 7 and 8. The histogram contains reservoir information from three sources such as reservoir properties calculated from well log data, upscaling procedure, and Gaussian algorithms-based modeling. The permeability values from upscaled cells and 3D permeability model are matched reasonably with the estimated permeability from well logs analysis (see Fig. 7a). The upscaled and 3D modeled permeability had lower values than well log permeability where permeability was less than $0.1 \mathrm{mD}$. The estimated permeability in upscaling and modeling was higher than well log permeability in $90-200 \mathrm{mD}$ range. Likewise, the matching of effective porosity with other estimation is good in high ranges of porosity as compared to low values. The high number of values of the well $\log$ at $0 \%$ hydrocarbon saturation than upscaled and modeled saturation shows that water saturation estimated by well log analysis was almost $4 \%$ greater than the upscaled reservoir (see Fig. 6). From well log analysis, the estimated average lithology of sandstone was $34.2 \%$, shaly sandstone was $44.6 \%$, and shale was $21.2 \%$.

The histogram of mechanical properties shows that there was a disturbance in the distribution of the reservoir mechanical properties as given in Fig. 8. Poisson's ratio and shear modulus had the difference between estimated and upscaled values at 0.0225 and $12 \mathrm{GPa}$, respectively.

Usually, the value of gamma ray ranges from 0 to 150 API for different formation depending upon the content of radioactive material (Rider and Kennedy 2002). Azeem 


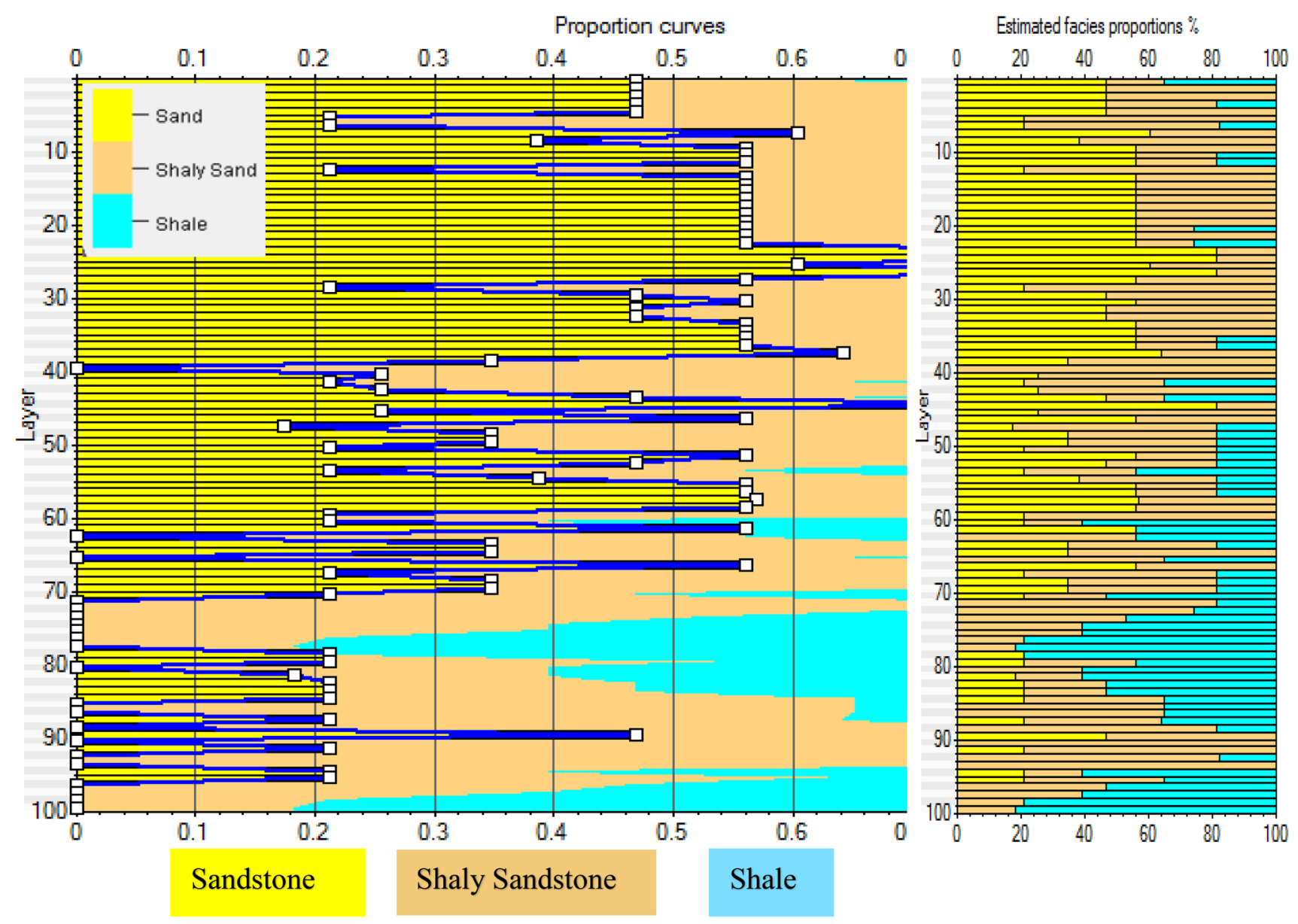

Fig. 6 Data analysis of facies modeling

et al. (2017) have used the value of 80 API for the identification of the depositional of the C-sand using gamma ray well log. The gamma ray cutoff for gas-bearing sands of the Lower Goru Formation is less than 80 API, for shaly sand is $80-120$ API, and shale is greater than 120 API (Azeem et al. 2017). In this study, the selected cutoff was decided on the basis of aforementioned literature. The cutoff selected for facies identification using gamma ray $\log$ was Facies $=\operatorname{If}(\mathrm{GR} \leq 60$, Sandstone, $\operatorname{If}(\mathrm{GR}>60$ And GR $\leq 85$, Shaly Sandstone, If(GR $>85$, Shale, otherwise undefined). The estimated facies from well log analysis were compared with facies as shown in Fig. 9.

\section{Results and discussion}

\section{Facies analysis}

It can be seen in Fig. 5 that there is a high structural dip around the Well-A which becomes gentle toward Well-E. The dipping of the strata toward the northeast is showing the same trend as reported by Ahmad et al. (2004) (Fig. 2). The lithology of the dipping strata is sandstone underlain by shale beds. The lithological and structural morphology suggests that the structure is almost of offlap shape. The stratigraphic deposition is indicating the regression event at the time of deposition of the formation which leads to the placement of sand from the shoreline into the marine sediments. The facies model of the studied reservoir interval shows that higher sand content is present in 

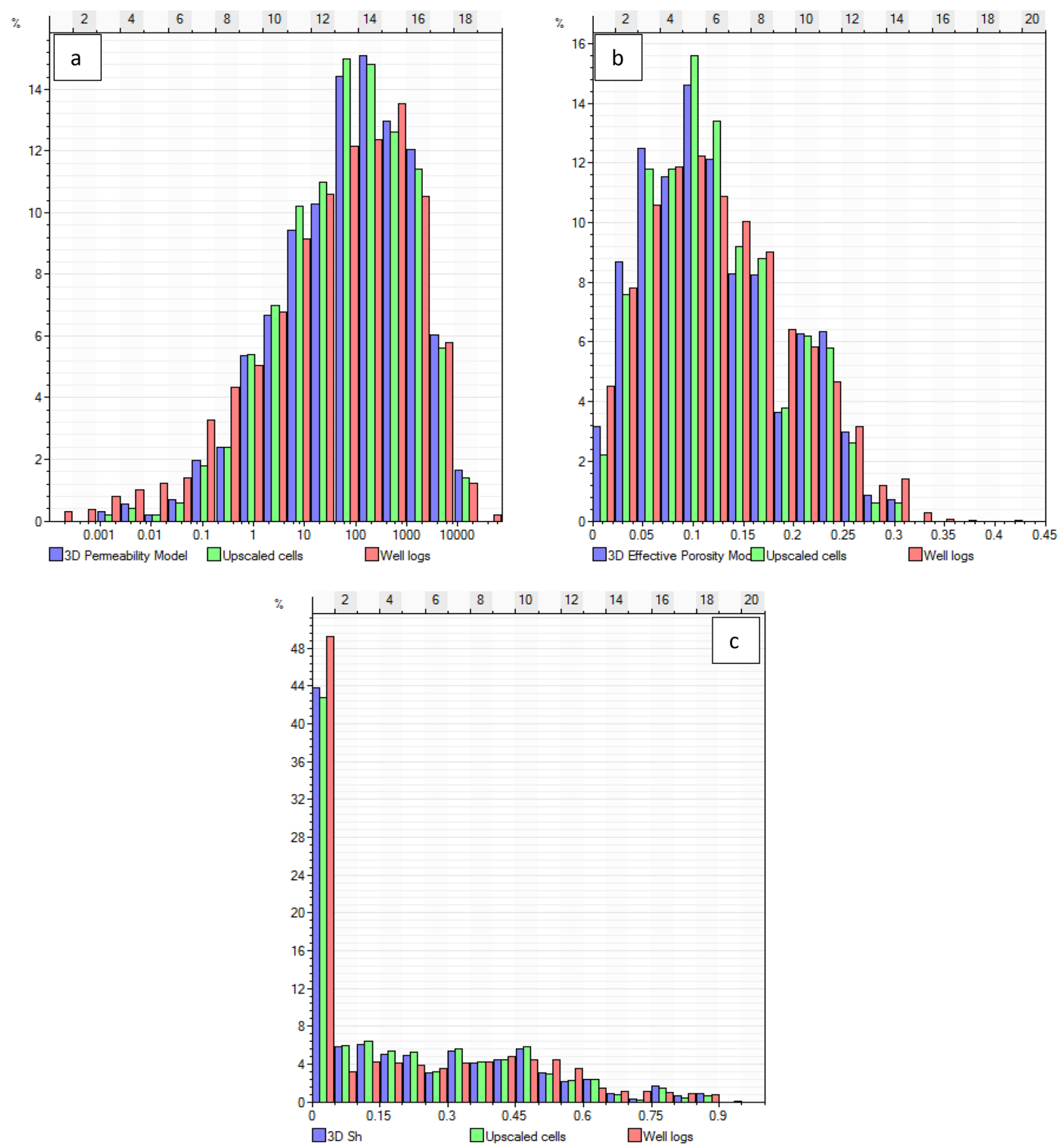

Fig. 7 Comparison of the estimated petrophysical properties distribution; a permeability, b effective porosity, $\mathbf{c}$ hydrocarbon saturation

the eastern part of the reservoir which also suggests that the direction of the deposition of the continental origin is from north-south or southeast to the western side of the reservoir. The resemblance between the prepared facies model and the stratigraphic model reported by Ahmad et al. (2004) emphasizes the validity of selected cutoff for facies calculator.
Naturally, every rock emits radioactive rays depending upon the extent of radioactive content. Usually, clay materials have a large amount of radioactive material leading to high emission of the gamma rays. In the absence of core data, the sedimentary facies can be identified on the basis of gamma ray radiation (Chow et al. 2005). The spatial distribution of facies was done by using the Gaussian 

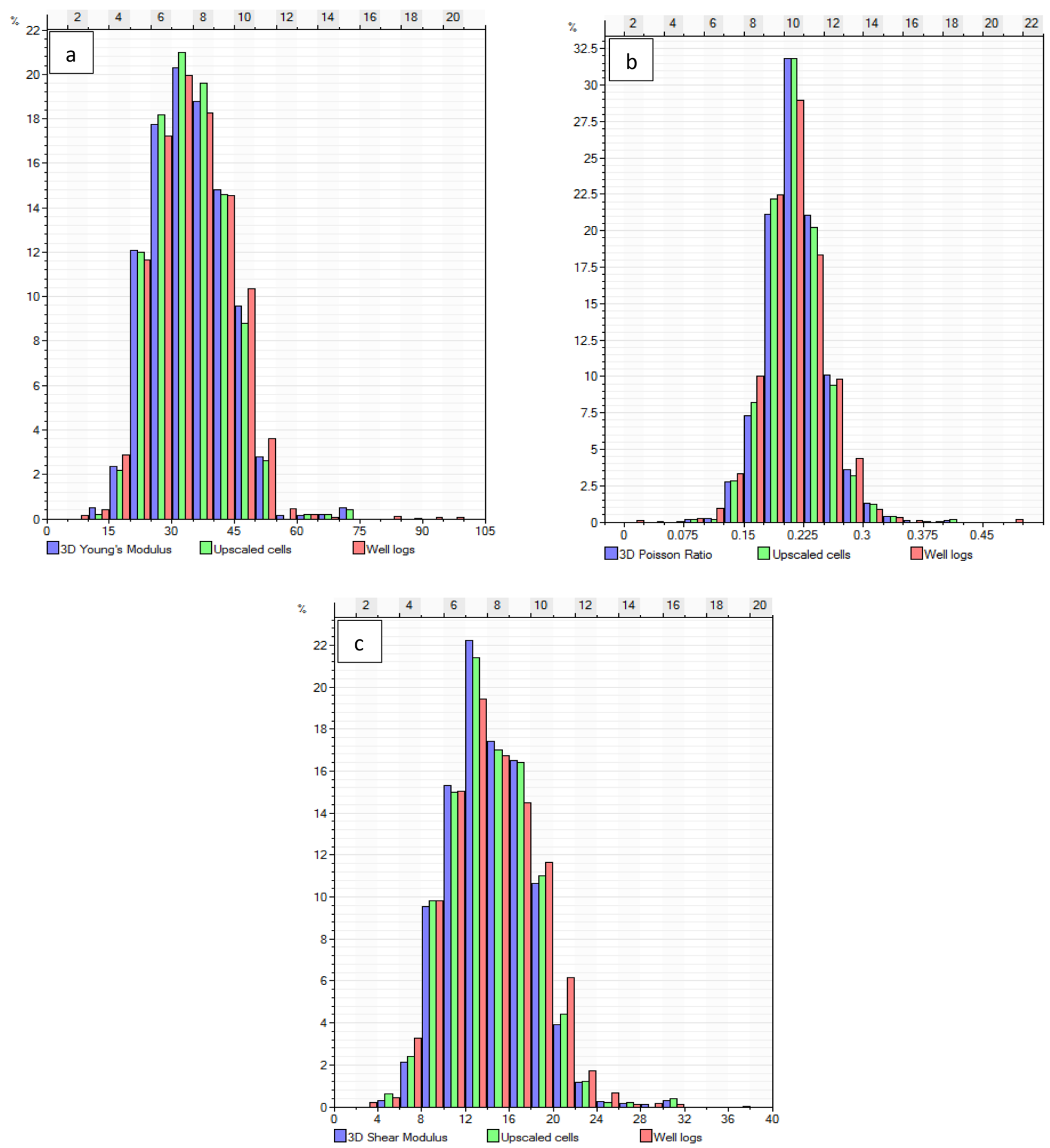

Fig. 8 Comparison of the estimated mechanical properties distribution; a Young's modulus, b Poisson's ratio, c shear modulus

indicating algorithm which is used to spread discrete data spatially. Sandstone was the dominant lithology in the upper part up to the depth of $3340 \mathrm{~m}$, while after the mentioned depth there were sandstone-shale beddings. In the upper part of the reservoir, GR values were in the range of $45^{\circ}-80^{\circ}$ API indicating dominant sandstone lithology.
For facies analysis, it was observed that the upper part of the $\mathrm{C}$-sand had a relatively high density of the sandstone layers as compared to lower part which showed that high reservoir potential was present around $3280 \mathrm{~m}$ depth. The highest thickness of the studied reservoir was $148 \mathrm{~m}$ in Well-A. In Well-A, there was high porosity in the upper 


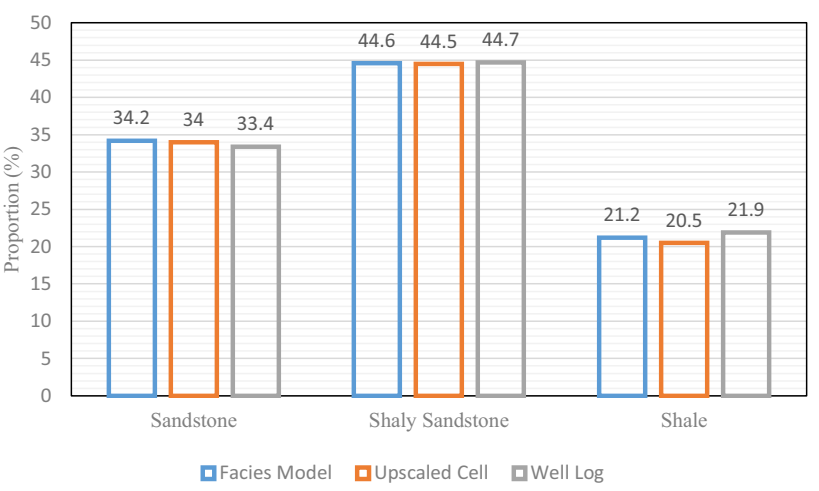

Fig. 9 Comparison of the facies percentages of well log analysis, upscaled logs, and facies model

part of the reservoir up to $3280 \mathrm{~m}$ which kept on decreasing to the end of the reservoir as shown in Figs. 6 and 10. In this study, the lithofacies and depositional environment have been interpreted on the basis of gamma ray pattern. From gamma ray, it is interpreted that the depositional environment of the Lower Goru Formation includes a deltaic channel, prograding delta distributaries, and delta front that is following coarsening upward grain size (Wandrey et al. 2004). The studied reservoir is of proximal delta front setting of which the thickness is decreasing from Well-A to Well-E. The inter-bedded sequence of the sand-clay beds is the result of the deposition of the sediments on the gentle slope (Ashraf et al. 2019).

The upper part of the reservoir in Well-A was composed of sandstone lithology which was turned to shaly sandstone formation and finally shale at the bottom depths of the reservoir. The mid-section of the reservoir was mainly composed of sandstone in Well-A which was turned into shale heterogeneities laterally. High shale content was seen around Well-D and Well-C which indicated a dipping toward WellE. Sandstone is present in the upper- to mid-range depths of the reservoir. Shale layers were seen in the lower part of the reservoir after $3340 \mathrm{~m}$ as indicated by high gamma ray values except in Well-E as provided in Fig. 10. The break in the reservoir lithological trend toward Well-E was due to anticipated heterogeneities. The moderate to high gamma ray values in the Well-B were showing shaly sandstone to shale lithology throughout the well. The reservoir potential in the studied formation is present in the upper part of the near in north of the Well-A as compared to sandstone beddings into upper to middle range depth around Well-B and Well-D (see Fig. 11).

\section{Petrophysical and geomechanical analysis}

Petrophysical and geomechanical analysis was carried out for five considered wells as results shown in Figs. 12, 16 and given in Table 2.

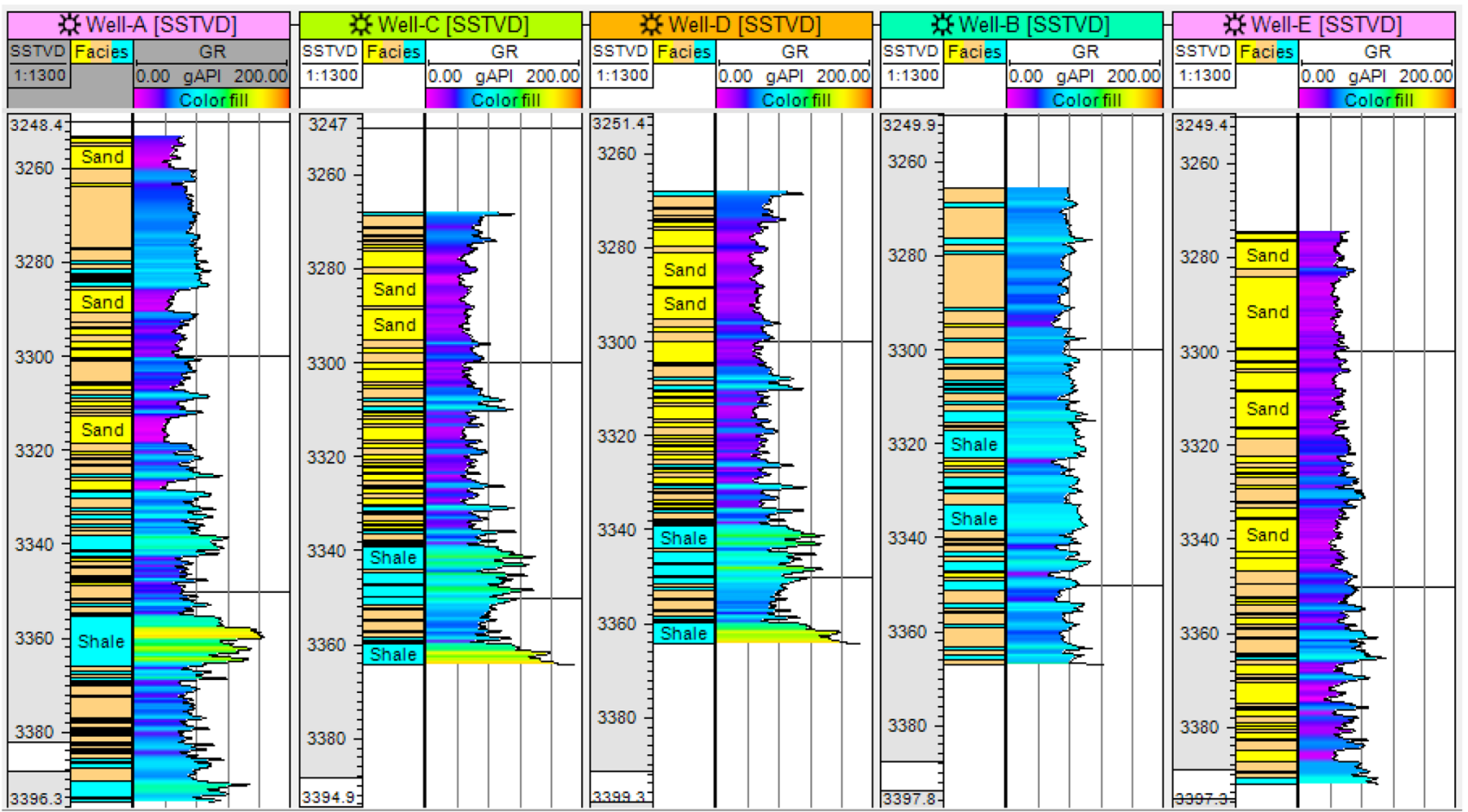

Fig. 10 Well correlation of the studied formation 
Fig. $113 \mathrm{D}$ facies model of the studied reservoir

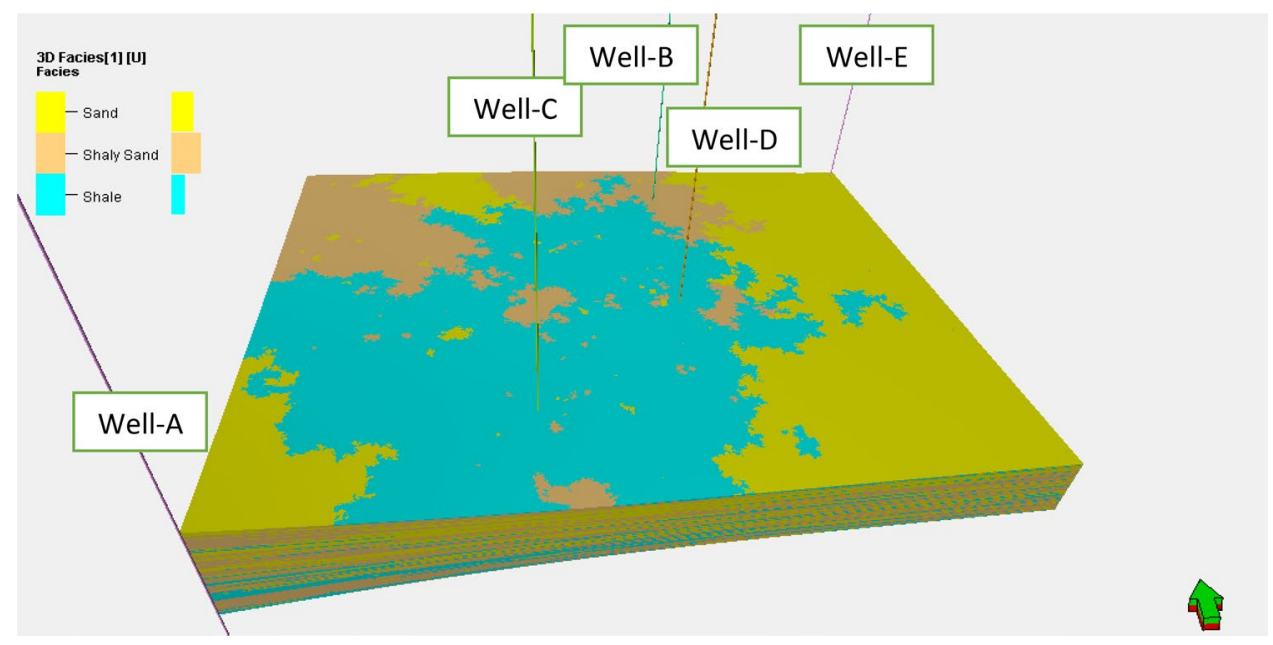

Fig. 12 Petrophysical and geomechanical properties in Well-A

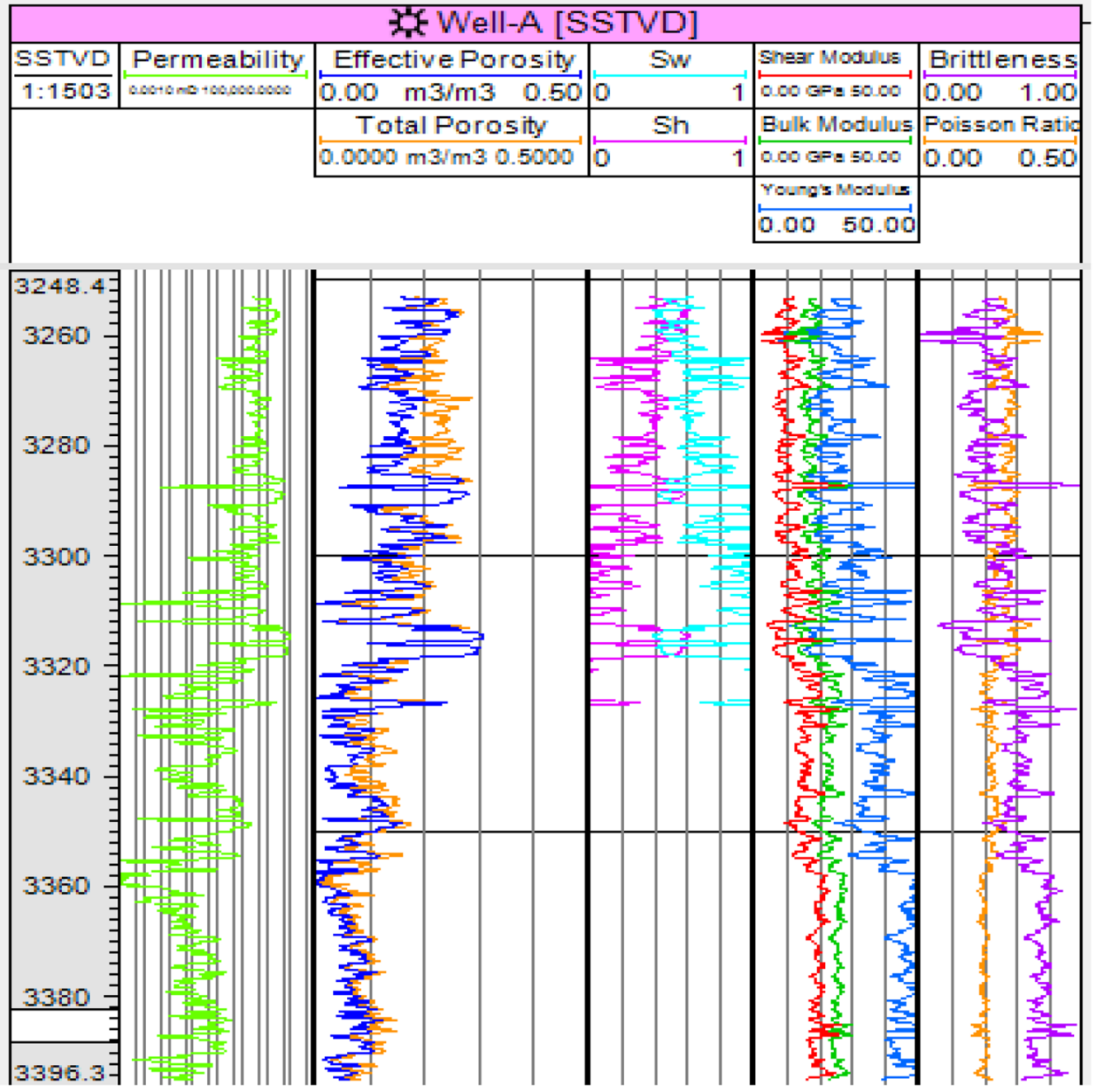

For Well-A, petrophysical and geomechanical analysis shows that the upper part of the reservoir was sandstone dominant which was causing high porosity behavior of the studied reservoir. A zone with $30 \%$ porosity was identified at $3314 \mathrm{~m}$ in Well-A. The area between total porosity and effective porosity curve is a qualitative signature of the volume of shale in the reservoir as shown in Fig. 12. The relative measure of shale volume in the wells is the measure of the petrophysical potential of the reservoir. The permeability information for the studied reservoir in Well-A was estimated using Morris and Biggs (1967) approach. The permeability and porosity are decreasing toward depth due to 
Table 2 Average values of petrophysical and geomechanical parameters of the studied reservoir

\begin{tabular}{lllllllll}
\hline Well name & Porosity (Dec) & Permeability $(\mathrm{mD})$ & $\begin{array}{l}\text { Hydrocarbon } \\
\text { saturation }\end{array}$ & $\begin{array}{l}\text { Bulk modu- } \\
\text { lus }(\mathrm{GPa})\end{array}$ & $\begin{array}{l}\text { Shear } \\
\text { modulus } \\
(\mathrm{GPa})\end{array}$ & $\begin{array}{l}\text { Young's } \\
\text { modulus } \\
(\mathrm{GPa})\end{array}$ & Poisson's ratio & Brittleness \\
\hline Well-A & 0.14 & 533.74 & 0.14 & 21.14 & 14.15 & 34.60 & 0.23 & 0.55 \\
Well-B & 0.13 & 122.32 & 0.17 & 21.02 & 13.95 & 34.14 & 0.23 & 0.41 \\
Well-C & 0.17 & 833.62 & 0.24 & 18.83 & 14.22 & 34.01 & 0.19 & 0.41 \\
Well-D & 0.17 & 1076.89 & 0.14 & 49.65 & 14.42 & 34.67 & 0.20 & 0.46 \\
Well-E & 0.17 & 974.66 & 0.26 & 20.64 & 15.20 & 36.44 & 0.20 & 0.38 \\
\hline
\end{tabular}

an increase of shaly content in the formation. In Well-A, the average value of hydrocarbon saturation was $20-40 \%$ up to $3290 \mathrm{~m}$ of the reservoir where dominant lithology was sandstone and high permeability and porosity were indicating a favorable petrophysical condition for a potential reservoir. The increase of permeability consistent with increasing porosity was showing the absence of significant heterogeneities in the reservoir. There is an inverse relationship between elastic modulus and the volume of clay (Shukla et al. 2013). The geomechanical moduli in the upper part of the reservoir were lowest up to $3316 \mathrm{~m}$, moderate to $3316-3346 \mathrm{~m}$, and highest for reservoir depth greater than $3346 \mathrm{~m}$. In our study, low values of Young's modulus, shear modulus, and bulk modulus at $3346 \mathrm{~m}$ were corresponding to the high quantity of shaly content. The brittleness is one of the most important properties of geomechanics which shows the hardness of the formation, behavior, and geometry of the propagating fractures. The high values of Young's modulus and low value of Poisson's ratio are the indications of high brittleness of the reservoir (Grieser and Bray 2007). The relation of the geomechanical properties with rock brittleness can be visualized from the 4th and 5th track of Fig. 10 where brittleness of the reservoir was increasing with increasing the geomechanical properties. At $3260 \mathrm{~m}$, the brittleness of the studied reservoir is up to $80 \%$ which showed the possibility of the desirable branched shaped fracture geometry. The geometry of the fractures is a tree-shaped fracture network in the reservoir zones with high brittleness, while a simple planer fracture network is produced in highly ductile rocks (Yasin et al. 2018). Excessive fracturing propagation and branched geometry are desirable in the stimulation of the unconventional reservoirs. The shales of the studied formation are considered as a strong candidate for shale gas production which needs to be studied more for successful exploration and production. There were tight sands present in the midpart of the reservoir in which the permeability was low up to $0.001 \mathrm{mD}$, while the porosity was lower than $5 \%$.

Figure 13 is for Well-B where the average value of hydrocarbon saturation was $30 \%$ up to the $3304 \mathrm{~m}$ depth of the reservoir. Hydrocarbon saturation was low in the middle of the reservoir as compared to the upper and lower part of the reservoir. A good correlation was seen between petrophysical properties estimated from well logs and routine core analysis as per the 1 st and 2 nd track of Fig. 13. The sudden increase of hydrocarbon saturation was seen at a $3350 \mathrm{~m}$ depth of reservoir in Well-B. The high value of porosity at $3300 \mathrm{~m}$ in Well-B was due to the low shale volume. Young's modulus was highest than the shear modulus and bulk modulus in Well-B. Young's modulus was decreasing with an increase in reservoir quality of the studied reservoir interval. There is a sudden decrease in porosity and permeability at 3320-3340 m due to an increase in the shale content of the reservoir. The reservoir zone saturated with water with shaly sandstone lithology was identified from 3310 to $3370 \mathrm{~m}$. The reservoir sections with high hydrocarbon saturations were seen in the upper and lower part of the reservoir at 3274-3378 $\mathrm{m}$ and 3360-3390 m, respectively.

Figure 14 is related to Well-C, and routine core analysis data of 225 core were used to access the level of correlation between estimated and measured petrophysical properties (see Table 1). Morris and Biggs (1967) equation was used to estimate the permeability of the sands of lower Goru reservoir using well log analysis (Ismail et al. 2017b). As shown in the first track of Fig. 14, good matching can be seen between measured and estimated permeability in up to $3280 \mathrm{~m}$ of the reservoir which decreased at $3300 \mathrm{~m}$ due to heterogeneity. The estimated porosity in Well-C matched very good with routine core analysis information which implied that porosity is less sensitive to heterogeneities as compared to permeability of the reservoir.

Permeability and porosity decreased along with the depth in Well-D due to the diminishing of sandy content in the reservoir which can be seen from 3340 to $3364 \mathrm{~m}$ depth (Figs. 5 and 18). The replaced lithology of the sand to shale in the lower part of the Well-D caused the reduction of the reservoir quality of the studied interval. The lithofacies of the studied reservoir interval is based on the gamma ray response against the specified lithology. The reported cutoff in the literature was used to generate facies log for the facies modeling (see Fig. 6). The water saturation was low up to $3306 \mathrm{~m}$ as compared to shaly sandstone in the middle section of the reservoir at $3310 \mathrm{~m}$ (see Fig. 15). The shear 
Fig. 13 Petrophysical and geomechanical properties in Well-B

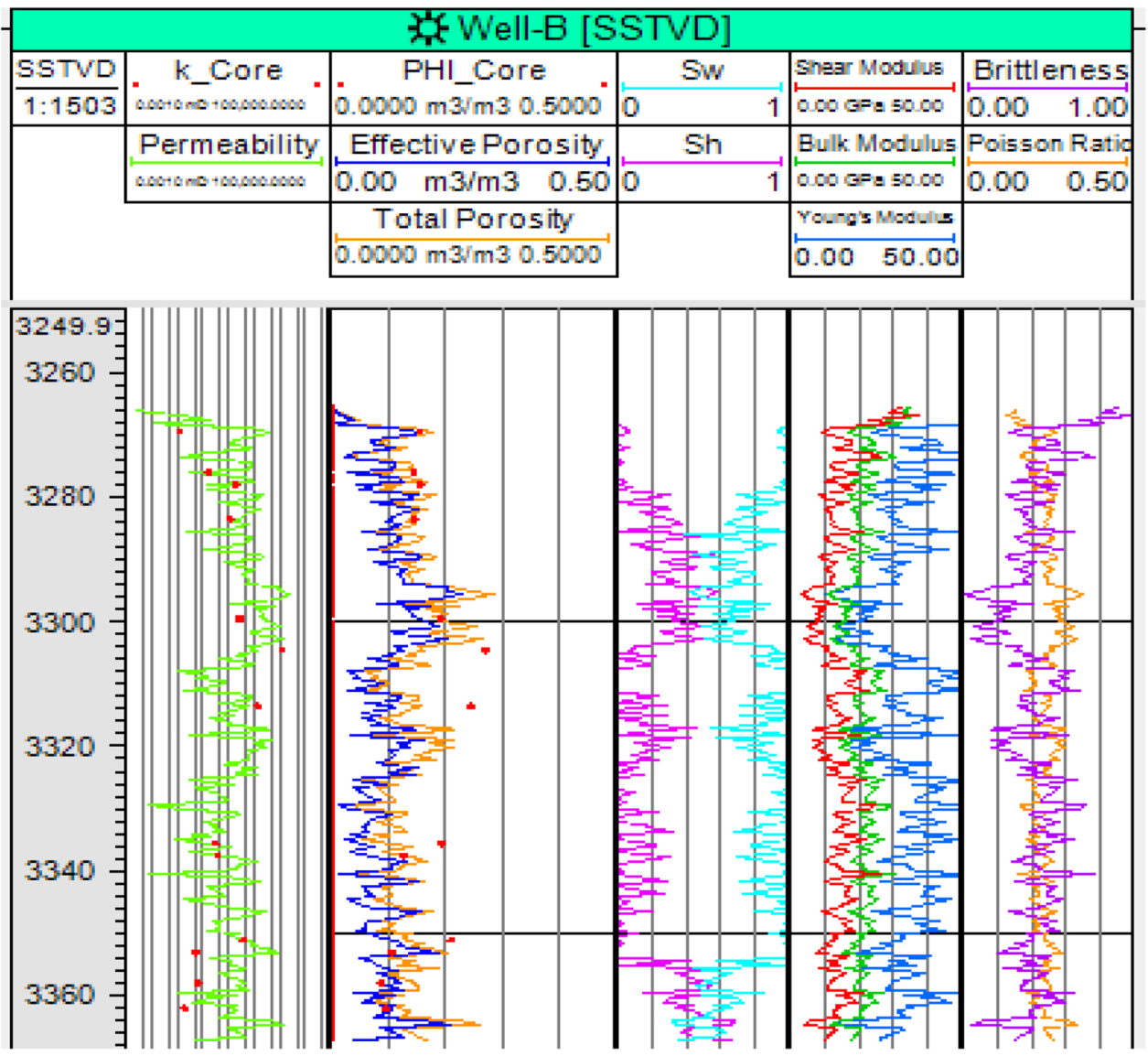

modulus and bulk modulus were relatively consistent with each other as compared to Young's modulus. The values of geomechanical moduli were highest in the sandy part of the reservoir at 3268-3308 $\mathrm{m}$ as compared to the shaly zone of $3332-3368 \mathrm{~m}$. The value of brittleness was nearly $40 \%$ in the entire reservoir coverage in the Well-C. As shown in figure, a drop of porosity and permeability is present at $3310 \mathrm{~m}$ due to shale laminations in Well-D. There were higher hydrocarbon saturations at 3290-3310 m, while fluctuations were seen in the trend due to sand-shale intercalations in 3310-3364 m of the reservoir. Porosity and permeability were low, while geomechanical properties were high at $3310 \mathrm{~m}$ in Well-D. The average value of brittleness in the studied reservoir in Well-D was 40-60\%.

Water saturation was high up to $3318 \mathrm{~m}$ while low in the lower part of the reservoir. In Well-E, average saturation in the upper part of the reservoir at 3280-3320 m was around 20-40\% (Fig. 16). In Well-E, the upper part was more brittle than the middle and lower part of the studied reservoir. The data points in the ternary diagram of the mineralogy of the reservoir were clustering near to quartz apex which showed that reservoir mineralogy has high quartz content (see Fig. 3). The high values of brittleness are due to quartz mineralogy in the reservoir lithology. According to Grieser and Bray (2007), ductile rocks have high Poisson's ratio and low Young's modulus, while brittle rock has high Young's modulus and low Poisson's ratio. The average Poisson's ratio at $3300 \mathrm{~m}$ was 0.3 which reached up to 0.1 at $3360 \mathrm{~m}$ due to variation in the petrophysical and geomechanical characterization of the reservoir (Grieser and Bray 2007).

\section{Sweet spot identification using color transformation overlay}

To understand the lateral and vertical behavior of the reservoir, 3D models were generated for effective porosity, permeability, hydrocarbon saturation, Young's modulus, bulk modulus, shear modulus, Poisson's ratio, and brittleness. Based on desired reservoir properties using a threedimensional model, ideal spots were identified for proposed wells using color transformation overlay of the studied reservoir. The area in the southwest of the Well-D is a potential reservoir in terms of lithology classification due to excessive sandstone beds (see Fig. 17). High values of permeable strata were seen around Well-A reaching up to $100,000 \mathrm{mD}$ which was decreasing toward the Well-D. The modeled permeability was showing very low permeability at the top of the reservoir. The permeability of the reservoir was found very good in the east of the Well-A. Most of the potential permeable sandstone was present up to the one-third of 
Fig. 14 Petrophysical and geomechanical properties in Well-C

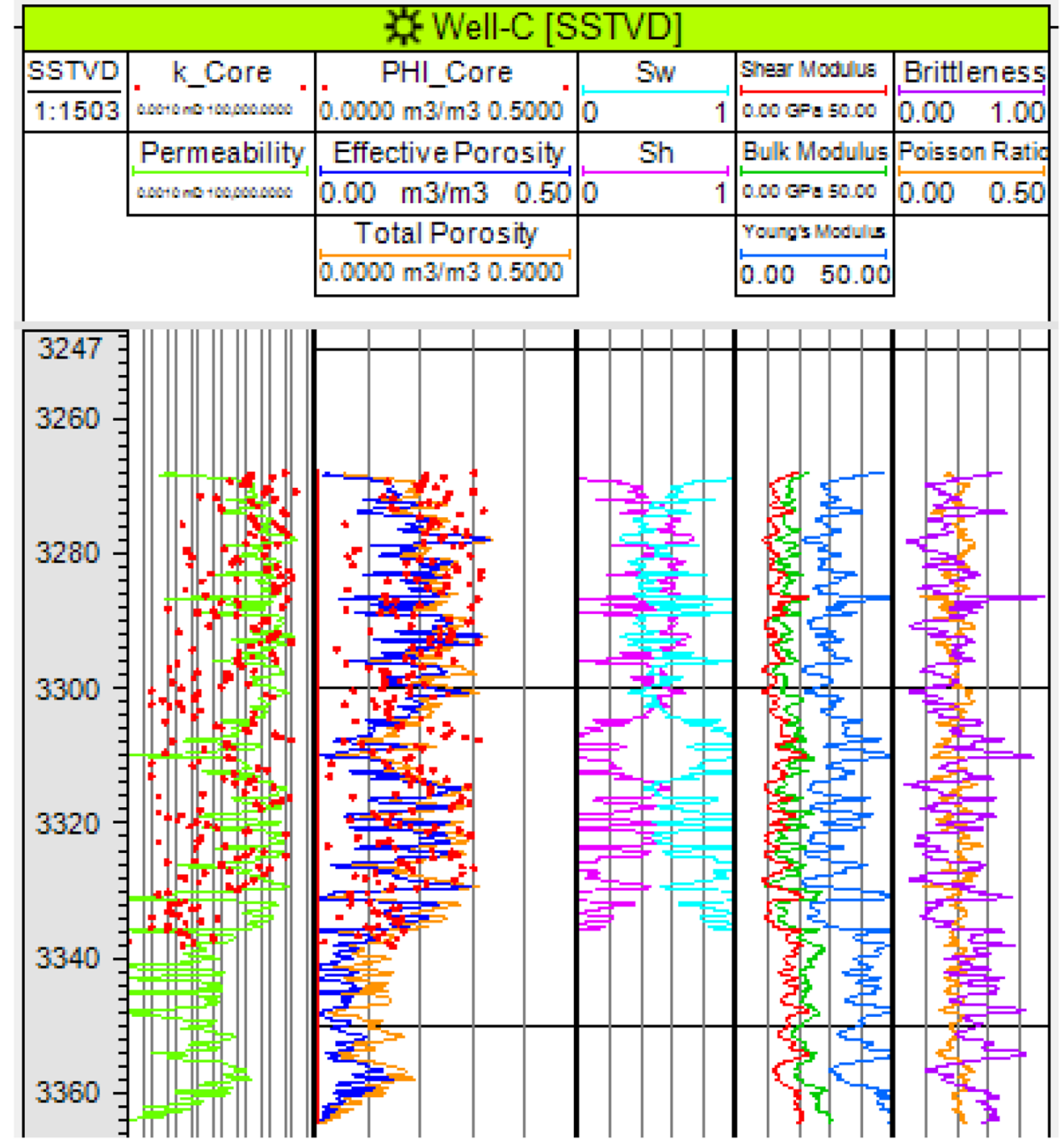

the reservoir from the top, while the lowest section of the wellbore was dominated by the shale. Figure 18 shows the 3D modeling of effective porosity showed that the upper part of the reservoir has low shale content due to dominant sandstone lithology which caused high effective porosity. The area around the Well-A has very good effective porosity which is reducing in the north direction of the Well-A. The top view visualization of the effective porosity model showed that area diagonal from Well-A to Well-E has low porosity. The area that presents in the south of the Well-E shows sandstone with very good effective porosity up to $25 \%$ due to very low shale content in the reservoir. The distribution of the shale in the reservoir was one of the main factors controlling the reservoir potential in the study area. Three realizations of the petrophysical modeling were observed for the studied reservoir. The distribution of the trend of the effective porosity can be seen by the red arrow in the box as shown in cross sections of the reservoir. Figure 19 shows the hydrocarbon saturation that is modeled to analyze the distribution of hydrocarbon accumulation spatially in the studied area. Almost 50\% saturation of hydrocarbon is identified near Well-A, while up to $80 \%$ saturation is observed in the middle and top zone of the reservoir in north of the Well-A in the studied area. The area of the reservoir in the east of Well-A is demonstrating the potential in terms of hydrocarbon saturation to midarea of the studied reservoir. On the basis of hydrocarbon accumulation, the reservoir area was divided into three parts; A, B, and C. Area A lies in the north of the Well-A which reaches up to $80 \%$ hydrocarbon saturation. The area in the east of the Well-A has been named $B$ where high values of hydrocarbon saturation can be seen in the upper part of the reservoir. Area $C$ is the high hydrocarbon saturation near Well-E which had a saturation of hydrocarbon more than $80 \%$.

The geomechanical behavior of the C-sand reservoir was accessed by the use of estimated geomechanical attributes of the reservoir from well log analysis and spatial distribution from the computer-assisted algorithm. The total

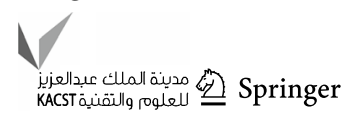


Fig. 15 Petrophysical and geomechanical properties in Well-D

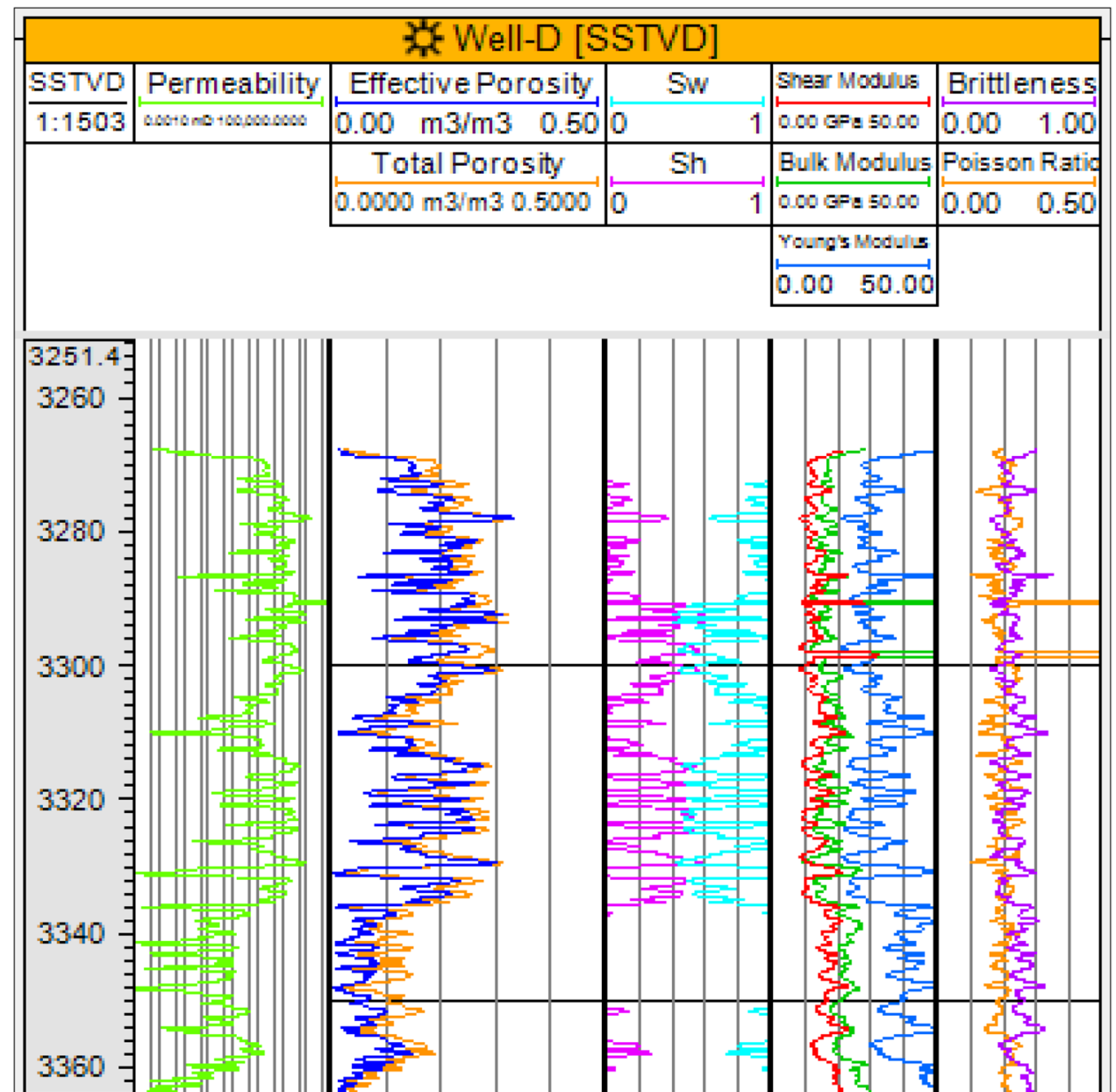

geomechanical behavior of the reservoir can be explained on the basis of the brittleness of studied reservoir rock. Brittleness is very low around Well-A which is increasing toward Well-E with a moderate range of $50 \%$ (see Fig. 20). The upper surface of the reservoir shows that the reservoir has brittleness of the reservoir is $50 \%$, but such magnitude varies along with depth in the studied reservoir. The reservoir around well-A has high brittleness at the bottom of the reservoir which is decreasing toward the east of the well-A. The brittleness around Well-D is almost 35\%. The areas which have low brittleness value were showing that there will be planer fractures in the reservoirs with low brittleness, while branched fractures will be produced in highly brittleness value. The geometry of the produced fractures is majorly controlled by geomechanical attributes particularly ductility, brittleness, and brittle ductile transition.

For sweet spot identification, geomechanical, facies, and petrophysical attributes are taken into consideration. Brittleness and hydrocarbon saturation have a common range from 0.0 to 1.0. The overlay technique is used for the identification of sweet spots in the formation. Higher values of hydrocarbon saturation with high brittleness values are favorable conditions for proposed wells in the studied formation. Firstly, the required petrophysical and mechanical are calculated using appropriate empirical approaches. After the formulation of the reservoir gridded model, the estimated properties are added in the model. To study the reservoir behavior spatially, the cross sections can be selected from the 3D model. After the formulation of the cross sections, the cross-sectional images can be overlaid to observe the transformation of the properties into a new required colored summation of the cross sections.

The overlay technique was performed on the $3 \mathrm{D}$ model of brittleness and hydrocarbon saturation to identify and understand the extent of the possible sweet spots in the reservoir as shown in Figs. 21 and 22. Each color in the model is correspondent to the magnitude of the respective value of either geomechanical or petrophysical attribute. The higher values of hydrocarbon saturation and brittleness with purple as color coding superimposed on each to give purple color as a final product of overlay, while in the absence of the potential petrophysical and geomechanical characterization of the reservoir, green or orange color areas in the final overlay are showing the regions 
Fig. 16 Petrophysical and geomechanical properties of the Well-E

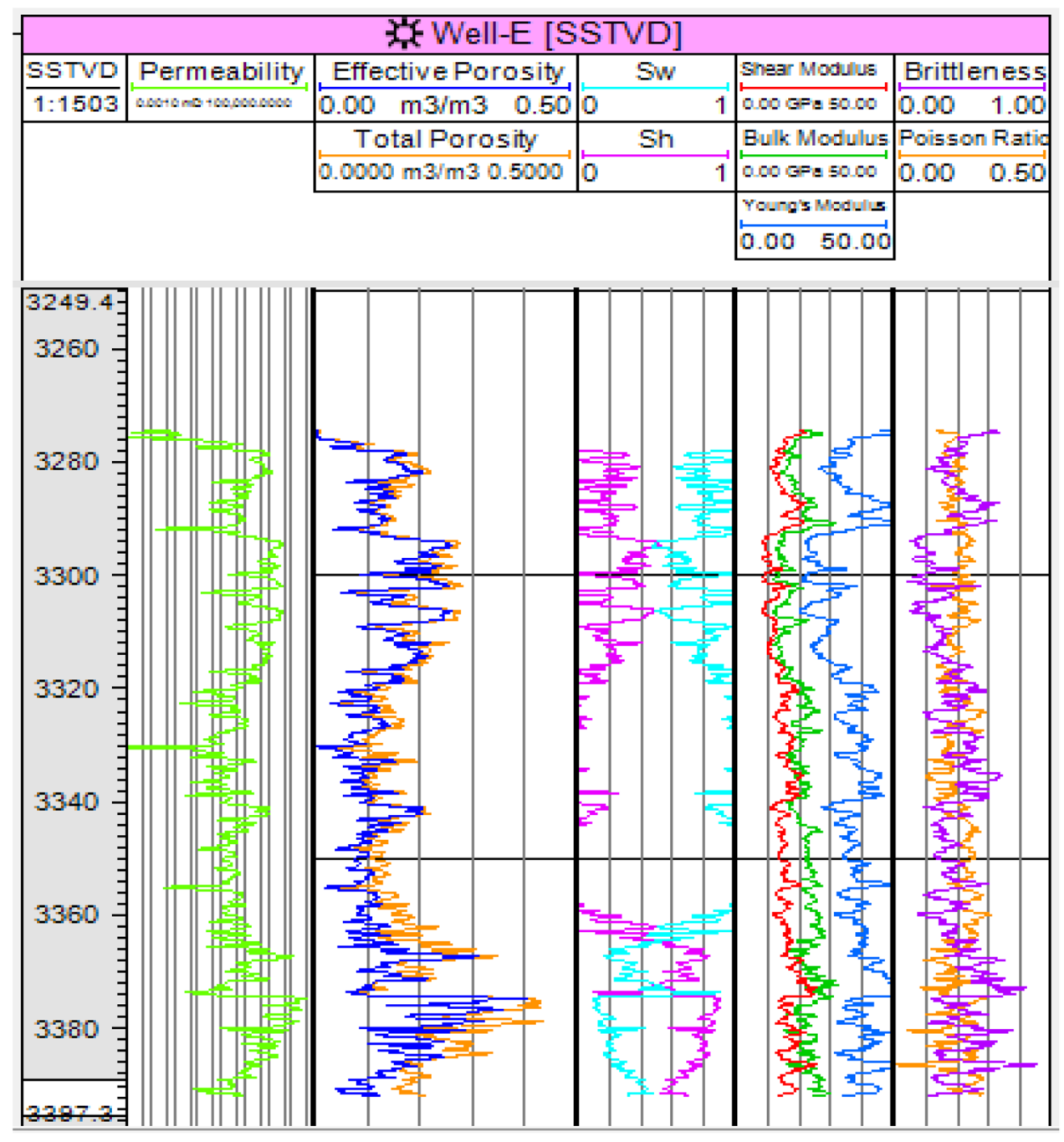

Fig. 17 3D permeability model of the studied reservoir

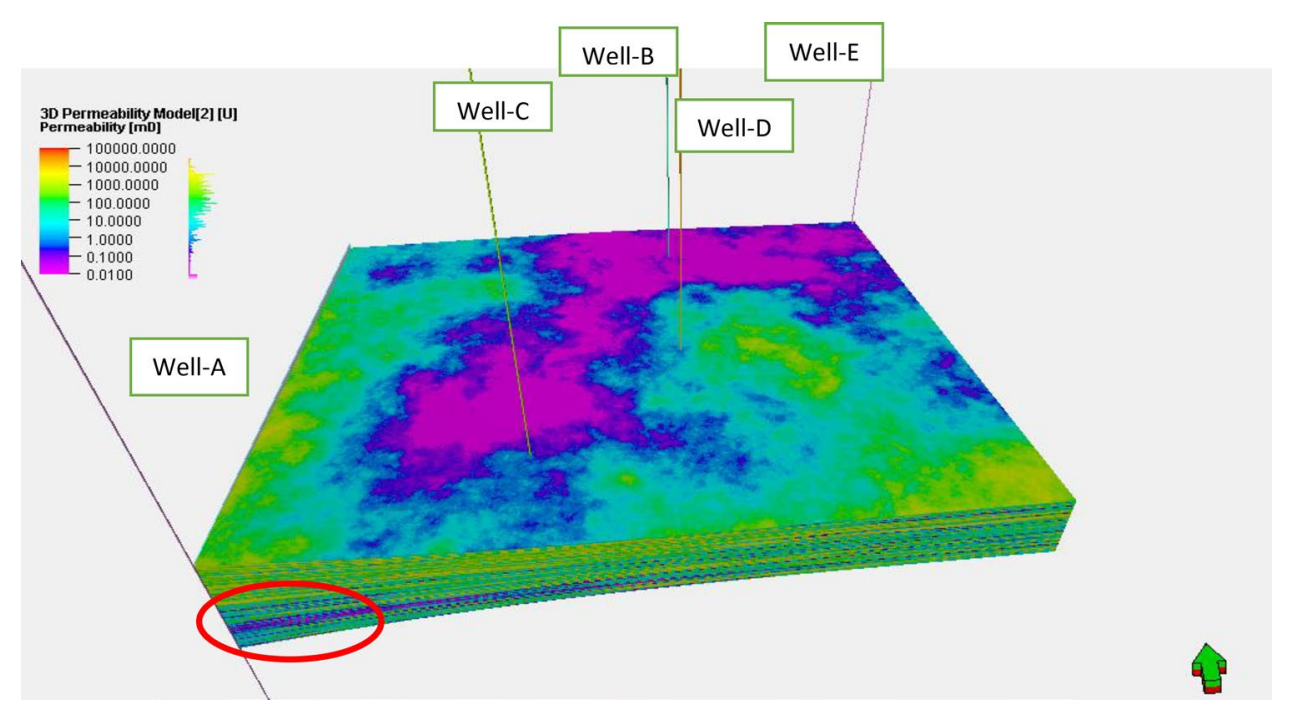


Fig. 18 3D effective porosity model of the studied reservoir
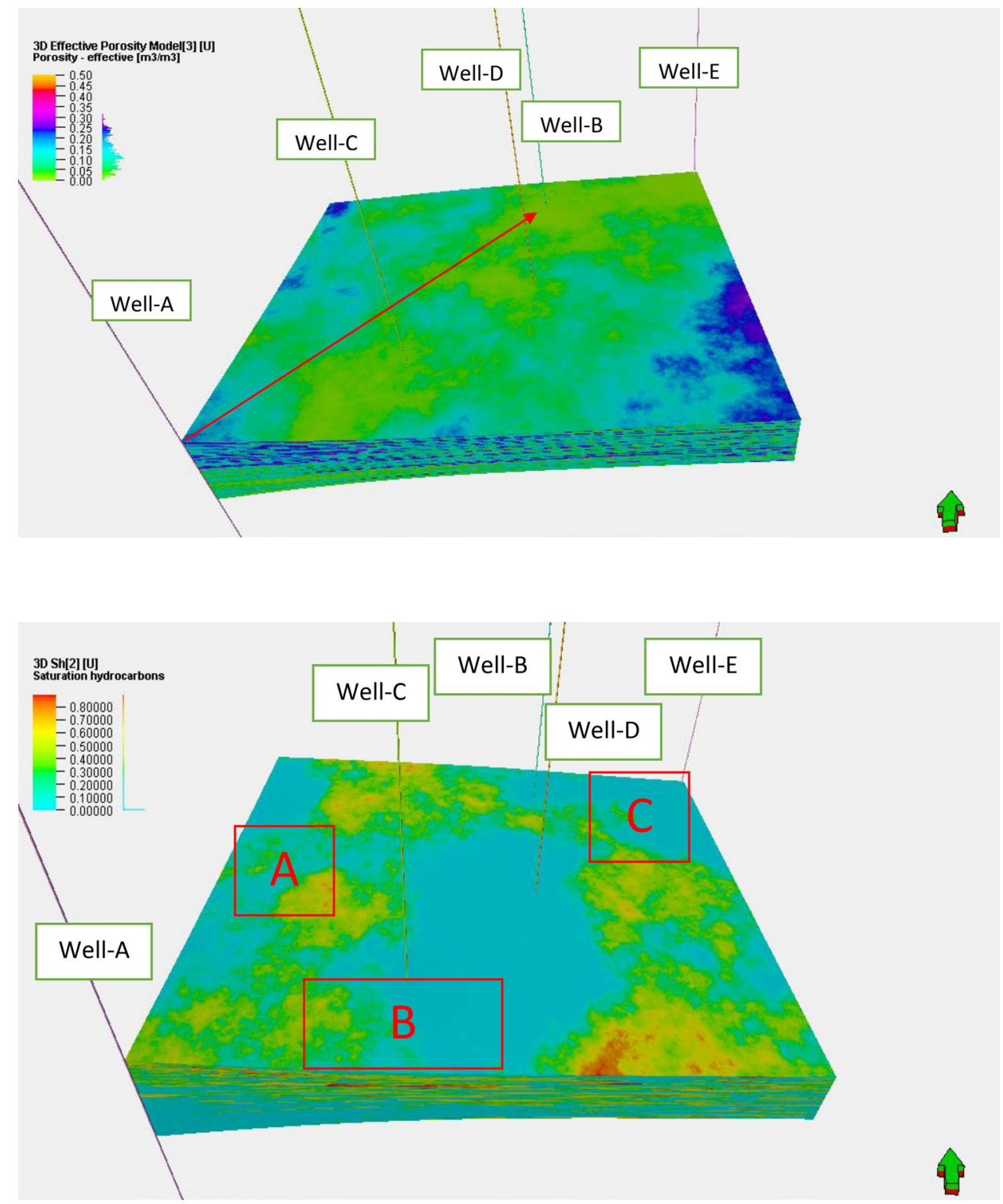

Fig. 19 3D hydrocarbon saturation model of the studied reservoir proposed as a development well in this area on the basis of a cross-sectional study of the prepared model (see Fig. 21). The location of the proposed well was away from the identified shallow sweet spots because of the lack of continuation of sweet spots along vertical and horizontal direction. The identified sweet spots are present at the shallow depths of the studied reservoir, while Well-P is proposed at a spot that has ideal conditions for hydrocarbon saturation and borehole stability. The marked area for the proposed well (Well-P) can be a good candidate for the potential reservoir which would have economical petrophysical and mechanical attributes status. The reservoir conditions around the proposed well were very tempting for prospective development of the field.

Figure 22 is the cross-sectional analysis of the color transformation overlay model that was done to understand the horizontal and vertical extension of the identified of colors in the overlay plot, four (4) sweet spots identified, marked by ovals in Fig. 21. A well (Well-P) is 
Fig. 20 3D brittleness model of the studied reservoir

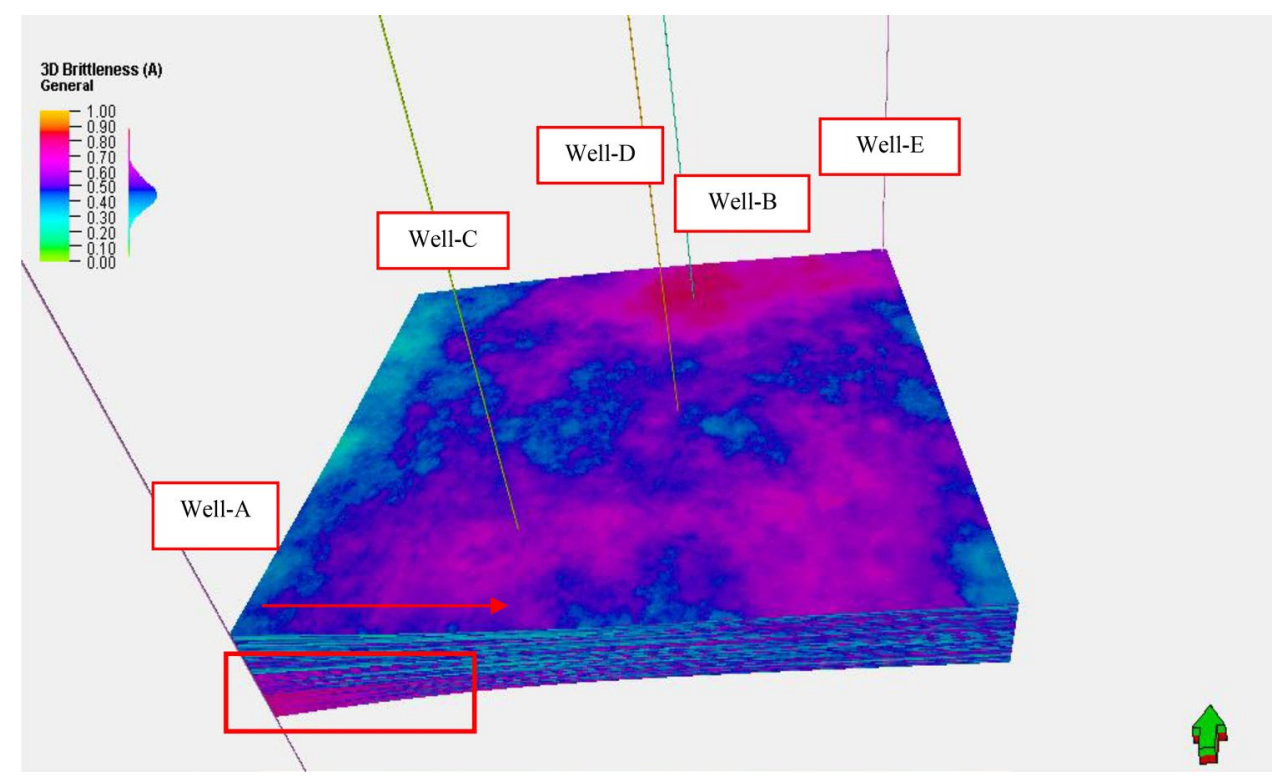

sweet spots. The areal extent of the sweet spots is understood for better realization of the S-1, S-2, and S-3 sweet spots extension. In cross section $1(\mathrm{C}-1)$, the spreading of the sweet spots (S-1, S-2, and S-3) is not consistent along with depth as obvious from the upper view of the reservoir. Laminations of high hydrocarbon saturation-bearing reservoir are seen around Well-E as shown in the S1 and $\mathrm{S} 2$ area. The spreading of the S-1 and S-2 was taken into the form of bedding in the east of the Well-A. A very clear indication of the sweet spot was seen around the Well$\mathrm{E}$ at the bottom of the reservoir which had high hydrocarbon saturation and brittleness value. The fourth sweet spot (S-4) is present in the southeast of the Well-D which had hydrocarbon saturation up to $70 \%$ and brittleness up to $65 \%$. The laminations along with the thickness of the reservoir which has a permeability of less than $0.01 \mathrm{mD}$ and porosity less than $10 \%$ can be considered as unconventional prospective with further investigation of other considerable factors.

The sweet spot technique was validated by application on a producing Well-X of Sawan gas field. It has been reported by Ashraf et al. (2019) that the production capacity of the Well-X is 4.702 MMScf gas that is very low as compared to the other wells of the field. So this possibility is concluded that the well is not located at an ideal condition. On the application of the transformation model on Well-X, it was seen that most of the well was not hit in the sweet spot zone as shown in Fig. 22. In Well-X, almost $40 \%$ of the reservoir, the interval had good geomechanical properties but the poor petrophysical potential that may be the major cause of lower potential of the well. The reduced petrophysical potential created such reservoir quality conditions that could not be favorable for hydrocarbon saturation development. The upper part of the reservoir had comparatively higher coverage of sweet spots.

\section{Conclusions}

Reservoir characterization is an integral part of the assessment of the petrophysical and geomechanical behavior of the reservoir. In this study, 3D reservoir characterization was performed to comprehend the identification and extension of the sweet spots of the reservoir using petrophysical and geomechanical modeling. The sequences of sandstone layers were dominant in the upper part of the C-sandstone, while lower part majorly contained sand-shale intercalations. High hydrocarbon saturation was present in the upper part of the sandstone lithology which decreased toward depth in all wells due to the reduction in reservoir potential. Brittleness of the reservoir was high around Well-A which was decreasing toward east of the Well-A.

The color transformation overlay technique is a powerful approach for the identification of sweet spots in the reservoir. Four sweet spots were identified in the studied reservoir based on the color transformation overlay approach which had heterogeneous continuity behavior in vertical and horizontal directions. The identification of sweet spots based on top view is not enough for the complete understanding of spreading in all directions. Cross-sectional analysis of the color transformation overlay model revealed that there is a sweet spot near Well-E in west which has ideal reservoir potential and place to consider another proposed well. 

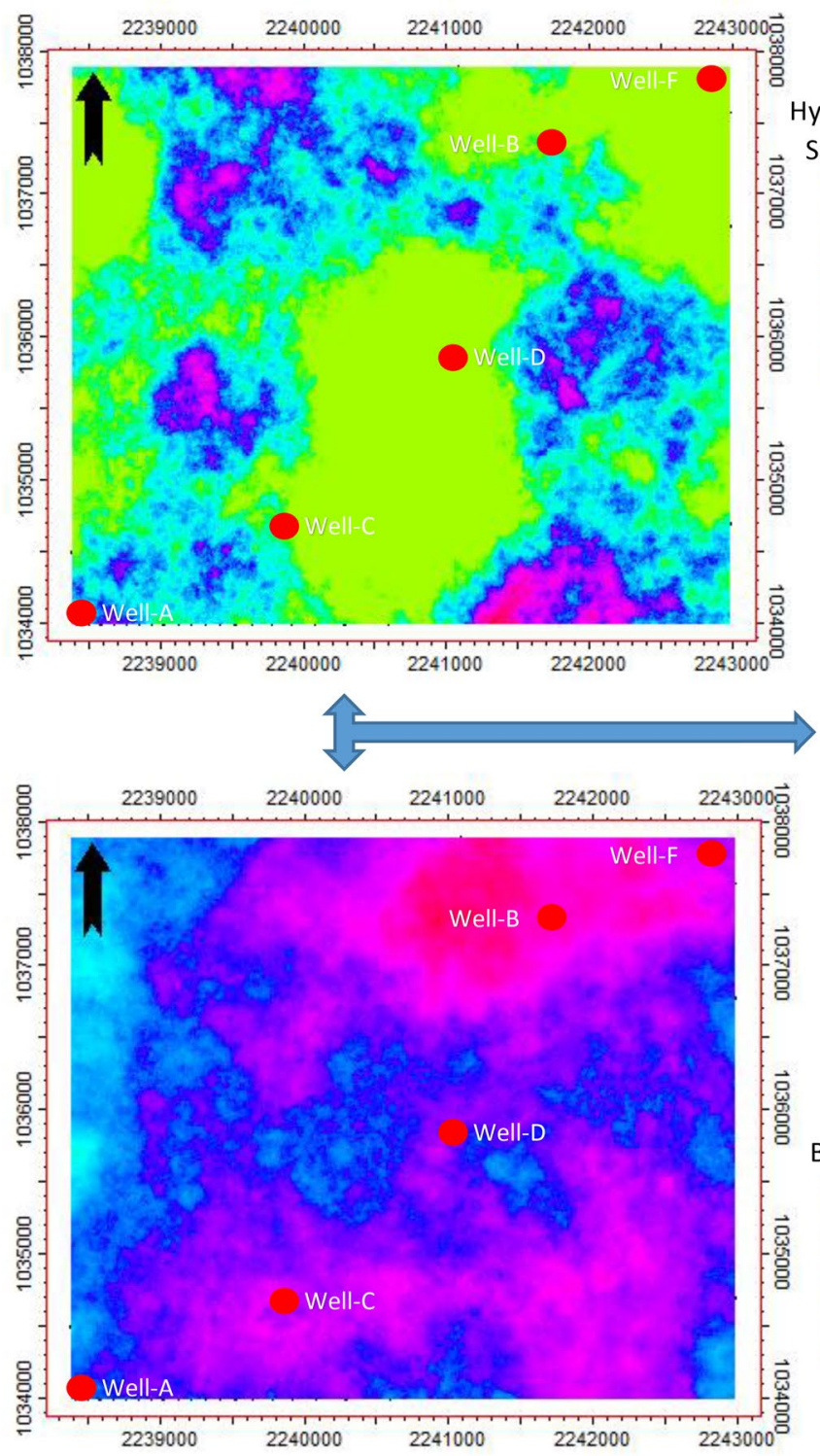

Hydrocarbon

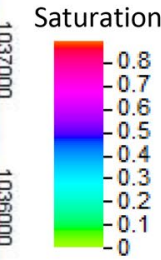

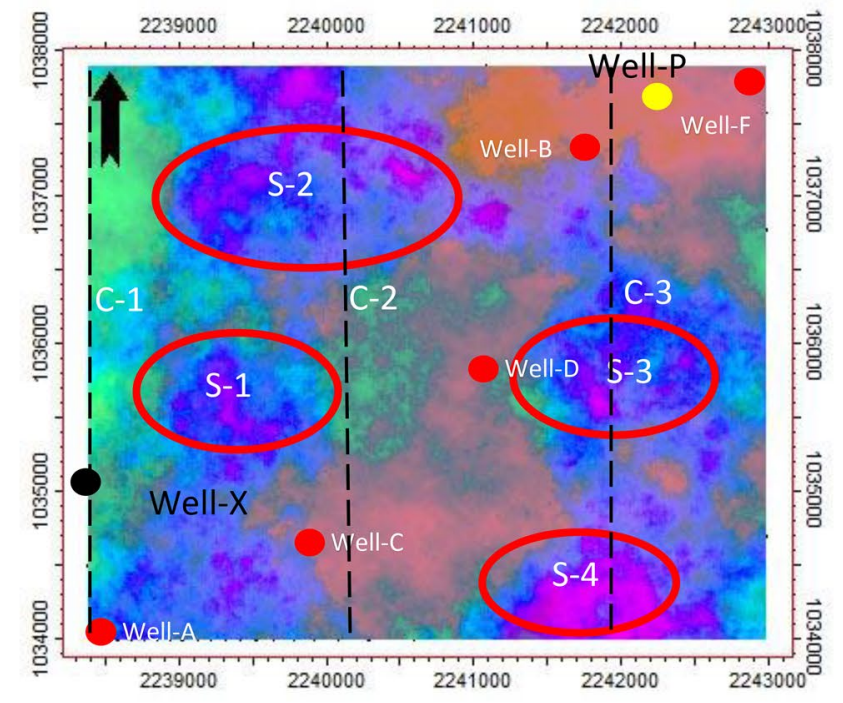

Fig. 21 Color transformation overlay analysis for sweet spot identification; the dominant colors in the color coding of the 3D model of brittleness and hydrocarbon saturation were pink, blue, purple, and

green. C-1, C-2, and C-3 are the cross sections considered for the study of the petrophysical properties along the depth
Fig. 22 Cross-sectional analysis of color transformation overlay model
Cross Section-1

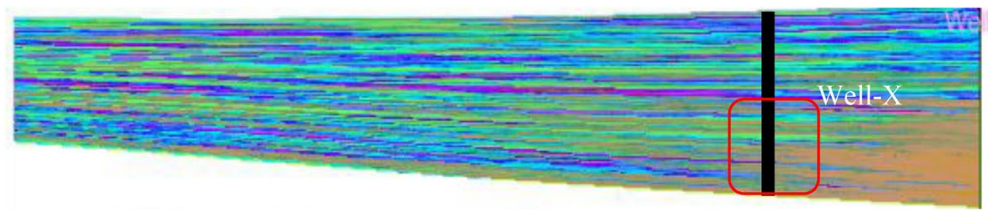

Cross Section-2
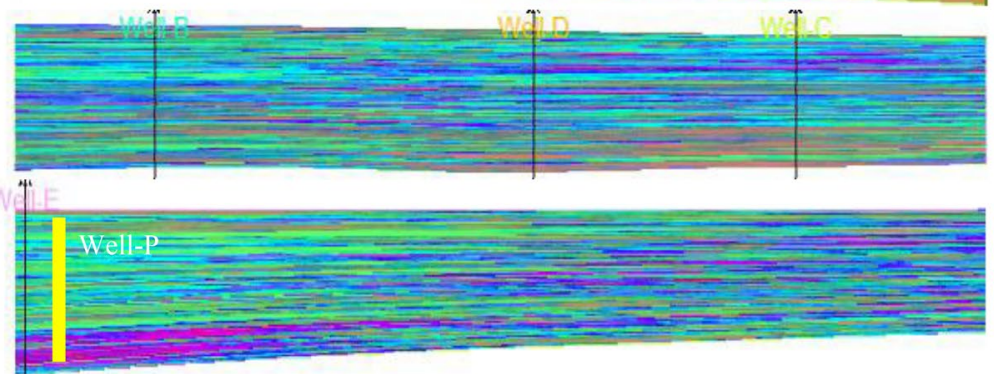

Cross Section-3

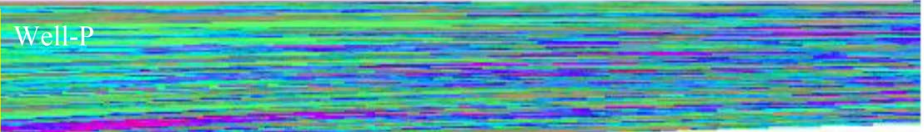

\section{Brittleness}

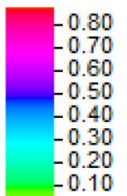


Open Access This article is licensed under a Creative Commons Attribution 4.0 International License, which permits use, sharing, adaptation, distribution and reproduction in any medium or format, as long as you give appropriate credit to the original author(s) and the source, provide a link to the Creative Commons licence, and indicate if changes were made. The images or other third party material in this article are included in the article's Creative Commons licence, unless indicated otherwise in a credit line to the material. If material is not included in the article's Creative Commons licence and your intended use is not permitted by statutory regulation or exceeds the permitted use, you will need to obtain permission directly from the copyright holder. To view a copy of this licence, visit http://creativecommons.org/licenses/by/4.0/.

\section{References}

Abdel-Fattah MI, Pigott JD, El-Sadek MS (2020) Integrated seismic attributes and stochastic inversion for reservoir characterization: insights from Wadi field (NE Abu-Gharadig Basin, Egypt). J Afr Earth Sci 161:103661. https://doi.org/10.1016/j.jafrearsci .2019 .103661

Ahmad N, Fink P, Sturrock S, Mahmood T, Ibrahim M (2004) Sequence stratigraphy as predictive tool in Lower Goru Fairway, Lower and Middle Indus Platform, Pakistan. In: PAPG, annual technical conference, pp 85-104

Adeoti L, Onyekachi N, Olatinsu O, Fatoba J, Bello M (2014) Static reservoir modeling using well $\log$ and 3-D seismic data in a $\mathrm{KN}$ field, offshore Niger Delta, Nigeria. Int J Geosci 5(01):93

Ahmad N, Chaudhry S (2002) Kadanwari gas field, Pakistan: a disappointment turns into an attractive development opportunity. Petrol Geosci 8(4):307-316. https://doi.org/10.1144/petgeo.8.4.307

Ahmed RA (1992) Structural styles and hydrocarbon prospects of Sibi foreland basin, Pakistan. Pak J Hydrocarb Res 4(1):31-40

Al-Amri M, Mahmoud M, Elkatatny S, Al-Yousef H, Al-Ghamdi T (2017) Integrated petrophysical and reservoir characterization workflow to enhance permeability and water saturation prediction. J Afr Earth Sci 131:105-116. https://doi.org/10.1016/j.jafre arsci.2017.04.014

Alfaaouri S, Riahi MA, Alizadeh N, Rezaei M (2009) Permeability prediction in an oil reservoir and construction of 3D geological model by stochastic approaches. J Appl Sci 9:2016-2030

Aliouane L, Ouadfeul S-A (2014) Sweet spots discrimination in shale gas reservoirs using seismic and well-logs data. A case study from the Worth Basin in the Barnett Shale. Energy Proc 59:22-27. https ://doi.org/10.1016/j.egypro.2014.10.344

Alshakhs M, Rezaee R (2019) Sweet-spot mapping through formation evaluation and property modelling using data from the Goldwyer Formation of the Barbwire Terrace, Canning Basin. Petroleum 5(1):13-29. https://doi.org/10.1016/j.petlm.2018.06.003

Archer S, Rasouli V (2012) A log based analysis to estimate mechanical properties and in situ stresses in a shale gas well in North Perth Basin. WIT Trans Eng Sci 81:163-174

Archie GE (1942) The electrical resistivity log as an aid in determining some reservoir characteristics. Trans AIME 146(01):54-62

Ashraf U, Zhu P, Yasin Q, Anees A, Imraz M, Mangi HN et al (2019) Classification of reservoir facies using well log and 3D seismic attributes for prospect evaluation and field development: a case study of Sawan gas field, Pakistan. J Petrol Sci Eng 175:338-351

Azeem T, Chun WY, Khalid P, Qing LX, Ehsan MI, Munawar MJ et al (2017) An integrated petrophysical and rock physics analysis to improve reservoir characterization of Cretaceous sand intervals in Middle Indus Basin, Pakistan. J Geophys Eng 14(2):212-225

Azeem T, Chun WY, Khalid P, Ehsan MI, Rehman F, Naseem AA (2018) Sweetness analysis of Lower Goru sandstone intervals of the Cretaceous age, Sawan gas field, Pakistan. Epis J Int Geosci 41(4):235-247

Berger A, Gier S, Krois P (2009) Porosity-preserving chlorite cements in shallow-marine volcaniclastic sandstones: evidence from Cretaceous sandstones of the Sawan gas field, Pakistan. AAPG Bull 93(5):595-615

Bhuiyan AH, Hossain S (2020) Petrographic characterization and diagenetic evaluation of reservoir sandstones from Smørbukk and Heidrun fields, offshore Norway. J Nat Gas Geosci. https://doi. org/10.1016/j.jnggs.2019.12.001

Changzi P, Jun P, Yanhui C, Hanrong Z (2014) Seismic prediction of sweet spots in the Da' anzhai shale play, Yuanba area, the Sichuan Basin. Nat Gas Ind B 1(2):185-191

Charlez PA (1997) Rock mechanics: petroleum applications. Editions Technip, Paris

Chopra S, Michelena RJ (2011) Introduction to this special section: reservoir characterization. Lead Edge 30(1):35-37

Chow JJ, Ming-Chung L, Fuh S-C (2005) Geophysical well log study on the paleoenvironment of the hydrocarbon producing zones in the Erchungchi Formation, Hsinyin, SW Taiwan. TAO Terr Atmos Oceanic Sci 16(3):531

Damsleth E (1994) Mixed reservoir characterization methods. In: University of Tulsa centennial petroleum engineering symposium. Society of Petroleum Engineers

Dykstra H, Parsons R (1950) The prediction of oil recovery by waterflood, secondary recovery of oil in the United States, principles and practice. American Petroleum Institute, Washington, DC

Elnaggar AA, Kassab MA, Abass AE (2018) Reservoir characterization utilizing core and wire line logging data for Kareem sandstone, Ashrafi oil Field, Gulf of Suez, Egypt. Egypt J Petrol 27(4):1013-1027

Fegh A, Riahi MA, Norouzi GH (2013) Permeability prediction and construction of 3D geological model: application of neural networks and stochastic approaches in an Iranian gas reservoir (journal article). Neural Comput Appl 23(6):1763-1770. https ://doi.org/10.1007/s00521-012-1142-8

Fjar E, Holt RM, Raaen AM, Risnes R, Horsrud P (2008) Petroleum related rock mechanics, 2nd edn. Elsevier Science, Burlington

Gaafar GR, Tewari RD, Zain ZM (2015) Overview of advancement in core analysis and its importance in reservoir characterisation for maximising recovery. In: SPE asia pacific enhanced oil recovery conference. Society of Petroleum Engineers

Glaser KS, Miller CK, Johnson GM, Toelle B, Kleinberg RL, Miller $P$ et al (2013) Seeking the sweet spot: reservoir and completion quality in organic shales. Oilfield Rev 25(4):16-29

Grieser WV, Bray JM (2007) Identification of production potential in unconventional reservoirs. In: Paper presented at the production and operations symposium, Oklahoma City, Oklahoma, USA

Holden L, Mostad P, Nielsen BF, Gjerde J, Townsend C, Ottesen S (2003) Stochastic structural modeling (journal article). Math Geol 35(8):899-914. https://doi.org/10.1023/b:matg.0000011584 .51162 .69

Ismail A, Yasin Q, Du Q, Bhatti AA (2017a) A comparative study of empirical, statistical and virtual analysis for the estimation of pore network permeability. J Nat Gas Sci Eng 45:825-839

Ismail A, Yasin Q, Du Q, Ahmed A, Khan N (2017b) Porosity-permeability relationship in distinct flow units in light of geophysical and laboratory methods. In: International geophysical conference, Qingdao, China, pp 272-276. https://doi.org/10.1190/igc2017-071

Ismail A, Yasin Q, Du Q (2018) Application of hydraulic flow unit for pore size distribution analysis in highly heterogeneous sandstone reservoir: a case study. J Jpn Petrol Inst 61(5):246-255

Jahandideh A, Jafarpour B (2016) Optimization of hydraulic fracturing design under spatially variable shale fracability. J Petrol Sci Eng 138:174-188 
Jennings JW Jr, Lucia FJ (2003) Predicting permeability from well $\operatorname{logs}$ in carbonates with a link to geology for interwell permeability mapping. SPE Reserv Eval Eng 6(04):215-225. https:// doi.org/10.2118/84942-PA

Kadri IB (1995) Petroleum geology of Pakistan. Pakistan Petroleum Limited, Karachi

Kazmi AH, Jan MQ (1997) Geology and tectonics of Pakistan. Graphic publishers, Santa Ana

Kelkar M, Perez G, Chopra A (2002) Applied geostatistics for reservoir characterization. Society of Petroleum Engineers, Richardson, TX, p 265

Kormaksson M, Vieira MR, Zadrozny B (2015) A data driven method for sweet spot identification in shale plays using well log data. In: SPE digital energy conference and exhibition. Society of Petroleum Engineers

Krois P, Mahmood T, Milan G (1998) Miano field, Pakistan: a case history of model driven exploration. In: Proceedings Pakistan petroleum convention, pp 112-131

Liang X, Wang G, Xu Z, Zhang J, Chen Z, Xian C et al (2016) Comprehensive evaluation technology for shale gas sweet spots in the complex marine mountains, South China: a case study from Zhaotong national shale gas demonstration zone. Nat Gas Ind B 3(1):27-36. https://doi.org/10.1016/j.ngib.2016.02.003

Martin JM, Malone DH (2017) Three-dimensional modeling of Pennsylvanian sandstone units in the mature Dudley oil field, Illinois, USA (journal article). J Petrol Explor Prod Technol 7(2):433-449. https://doi.org/10.1007/s13202-016-0304-0

Morris RL, Biggs WP (1967) Using log-derived values of water saturation and porosity. In: Paper presented at the SPWLA 8th annual logging symposium, Denver, Colorado

Mukerji T, Dvorkin J (2009) The rock physics handbook, 2nd edn. Cambridge University Press, Cambridge

Munir K, Iqbal MA, Farid A, Shabih SM (2011) Mapping the productive sands of Lower Goru Formation by using seismic stratigraphy and rock physical studies in Sawan area, southern Pakistan: a case study. Journal of Petroleum Exploration and Production Technology $1(1): 33-42$

Qingcai Z, Sheng C, Pei H, Qing Y, Xiaolong G, Peng C et al (2018) Quantitative prediction of shale gas sweet spots based on seismic data in Lower Silurian Longmaxi Formation, Weiyuan area, Sichuan Basin, SW China. Petrol Explor Dev 45(3):422-430

Rahman K, Gui F (2016) Geomechanical sweet spot identification in unconventional resources development. In: SPE Asia pacific oil and gas conference and exhibition. Society of Petroleum Engineers

Rider M, Kennedy M (2002) The geological interpretation of well logs. Rider-French Consulting Ltd., Sutherland

Rojas LF, Peña YQ, Carrillo Z (2016) Brittleness analysis: a methodology to identify sweet spots in shale gas reservoirs. In: SPE Argentina exploration and production of unconventional resources symposium. Society of Petroleum Engineers

Saccomano AF, Savioli GB (2007) Estimation of rock properties applying an alternative geostatistical autocorrelation tool. In: Paper presented at the Latin American and Caribbean petroleum engineering conference, Buenos Aires, Argentina
Sahito AG, Solangi SH, Usmani P, Brohi IA, Napar LD, Khokhar Q (2013) Sedimentologic studies of Upper sands of Lower Goru Formation based on well cuttings and wireline logs from wells of $\mathrm{X}$ field in the subsurface of Sindh Monocline, Southern Indus Basin, Pakistan. Sindh Univ Res J SURJ (Sci Ser) 45(2):341-352

Sena A, Castillo G, Chesser K, Voisey S, Estrada J, Carcuz J et al (2011) Seismic reservoir characterization in resource shale plays: stress analysis and sweet spot discrimination. Lead Edge 30(7):758-764

Sharma O, Arya O (2006) Formation strength estimation from well log data for sand cut analysis in Tapti-Daman area, Western Offshore Basin, India

Shukla R, Ranjith P, Choi S, Haque A, Yellishetty M, Hong L (2013) Mechanical behaviour of reservoir rock under brine saturation. Rock Mech Rock Eng 46(1):83-93

Stein N (1976) Mechanical properties of friable sands from conventional log data (includes associated papers 6426 and 6427). J Petrol Technol 28(07):757-763

Sun T, Merletti G, Patel H, Cadwallader S, Graff MC, Wampler J, et al (2015) Advanced petrophysical, geological, geophysical and geomechanical reservoir characterization-key to the successful implementation of a geo-engineered completion optimization program in the Eagle Ford shale'. In: Unconventional resources technology conference, San Antonio, Texas. Society of Exploration Geophysicists, American Association of Petroleum, pp 694-703

Tennant SH, Giles MR (2014) Sweet spots: what are they, where are they, how are they created and are they important anyway? In: Paper presented at the SPE/EAGE European unconventional resources conference and exhibition, Vienna, Austria

Thadani S (1992) Stochastic imaging for reservoir characterization. In: 54th EAEG meeting

Tiab D, Donaldson EC (2011) Petrophysics: theory and practice of measuring reservoir rock and fluid transport properties. Gulf Professional Publishing, Houston

Wandrey CJ, Law B, Shah HA (2004) Sembar Goru/Ghazij composite total petroleum system, Indus and Sulaiman-Kirthar geologic provinces, Pakistan and India. US Department of the Interior, US Geological Survey

Yang X, Wang X, Aoues A, Ouenes A (2015) Sweet spot identification and prediction of Frac stage performance using geology, geophysics, and geomechanics-application to the Longmaxi Formation, China'. In: SPE Asia pacific unconventional resources conference and exhibition. Society of Petroleum Engineers

Yasin Q, Du Q, Sohail GM, Ismail A (2018) Fracturing index-based brittleness prediction from geophysical logging data: application to Longmaxi shale (journal article). Geomech Geophys Geo Energy Geo Resour 4(4):301-325. https://doi.org/10.1007/s4094 8-018-0088-4

Publisher's Note Springer Nature remains neutral with regard to jurisdictional claims in published maps and institutional affiliations. 